\title{
PARCELA ZA ČP. 10/I V CHRUDIMI. JEJÍ VÝVOJ A ŽIVOTNÍ PROSTŘEDÍ
}

\author{
JAN FROLÍK - ROMANA KOZÁKOVÁ - JAN MUSIL - KATEŘINA VAĎUROVÁ
}

\begin{abstract}
Abstrakt: V roce 2006 byl proveden jeden z nejrozsáhlejšich záchranných archeologických výzkumů v městském jádru nékdejšiho královského věnného mésta Chrudimi. Výzkum pokryl plochu tři parcel - zaniklých čp. 14/I a 15/I a část dvorku a zahrady za čp. 10/I. Při výzkumu na parcele čp. 10/I byla objevena a detailně prozkoumána středověká odpadni jímka, ze které pocházi početný soubor nálezů pokrývající obdobi od konce 14. do poloviny 17. století umožňujici detailní vhled do domácnosti chrudimského měštana tohoto období.
\end{abstract}

Klíčová slova: město - parcela-odpadni jímka - sklo-keramika.

\section{A plot behind house no. 10/I in Chrudim. Its development and environment}

Abstract: In 2006, some of the most extensive rescue archaeological excavations were carried out in the urban core of the former royal dowry town of Chrudim. The research covered the area of three plots-defunct houses nos. 14/I and 15/I and a part of the yard and garden behind house no. 10/I. During the research on plot no. 10/I, a medieval refuse pit was discovered and examined in detail. It yielded a large collection of finds spanning the period from the end of the 14th century until the mid-17th century, providing a detailed insight into the household of a Chrudim burgher of this period.

Key words: town - plot-refuse pit-glass-ceramic.

\section{1 Úvod. Okolnosti výzkumu}

Parcela čp. 10/I v Chrudimi byla zčásti zkoumána v roce 2006 jako součást rozsáhlého plošného záchranného výzkumu, který zahrnul ještě parcely čp. 14/I a čp. 15/I (Frolík-Musil 2007; 2010). Zkoumaná plocha přiléhala zejména k Hradební ulici, parcela domu čp. 10/I se však svou čelní stranou obrací do souběžné ulice Rybičkovy. V době výzkumu tvořila užší obdélný pás, který vyplňoval plochu mezi oběma ulicemi, tj. zadní stranou přiléhal ke Hradební ulici. Parcela byla rozdělena na dvě části. Polovina přiléhající k Rybičkově ulici je zastavěna budovou se středověkými kořeny a malým nepravidelným dvorkem. Polovina sousedící s Hradební ulicí byla tvořena zarostlou neudržovanou zahradou. Výzkum zjistil, že zahrada původně tvořila samostatné městiště, vyplněné z převážné části obytným domem s počátky ve druhé polovině 13. století a s dalším složitým stavebním vývojem až do třicetileté války, kdy zanikl (obr. 1). Obnoven již nebyl. Z této situace vyplynulo, že původní rozsah parcely domu čp. 10/I zhruba odpovídal až do třicetileté války ploše současného domu a zmíněného dvorku. Na něj se soustředí naše pozornost.

Terénní situace svým počátkem sahají až do pravěku (Novák 2010) a pokrývají kontinuálně období od 9. století do lokace vrcholně středověkého města před rokem 1276 (Frolík-Sigl 1998). Významnou součástí nálezové situace vrcholně středověkého období byly početné jímky a odpadní jámy s nálezy od přelomu 13. a 14. století až do 18. století. Jejich rozmístění na zkoumaných parcelách bylo nerovnoměrné, ale významný vliv na naše poznání měla možnost zkoumat parcelu v úplnosti nebo jen zčásti. To platí zejména pro parcelu domu čp. 10/I, z níž byla poznána pouze malá (východní) část zahrnutá do stavební jámy projektu, který vyvolal záchranný výzkum. Proto můžeme k domu čp. 10/I vztáhnout pouze jedinou zkoumanou jímku ze sektoru C1 - jímku 973.

Stejně jako všechny ostatní objekty byla i tato jímka zkoumána po přirozených vrstvách, dovolujících detailně sledovat proces zaplňování. I zde platí, že původně měkký zásyp jímky sesedal a vzniklá proláklina byla dodatečně zasypávána (např. jímky 938 a 962 - Frolík-Kozáková-Musil 2018; Frolík-Kozáková-Musil-Bad’urová 2020). Jednalo se o dlouhodobý proces a jímka 973 se projevovala v podobě mírné prolákliny v soudobé dlažbě již před zahájením výzkumu. 


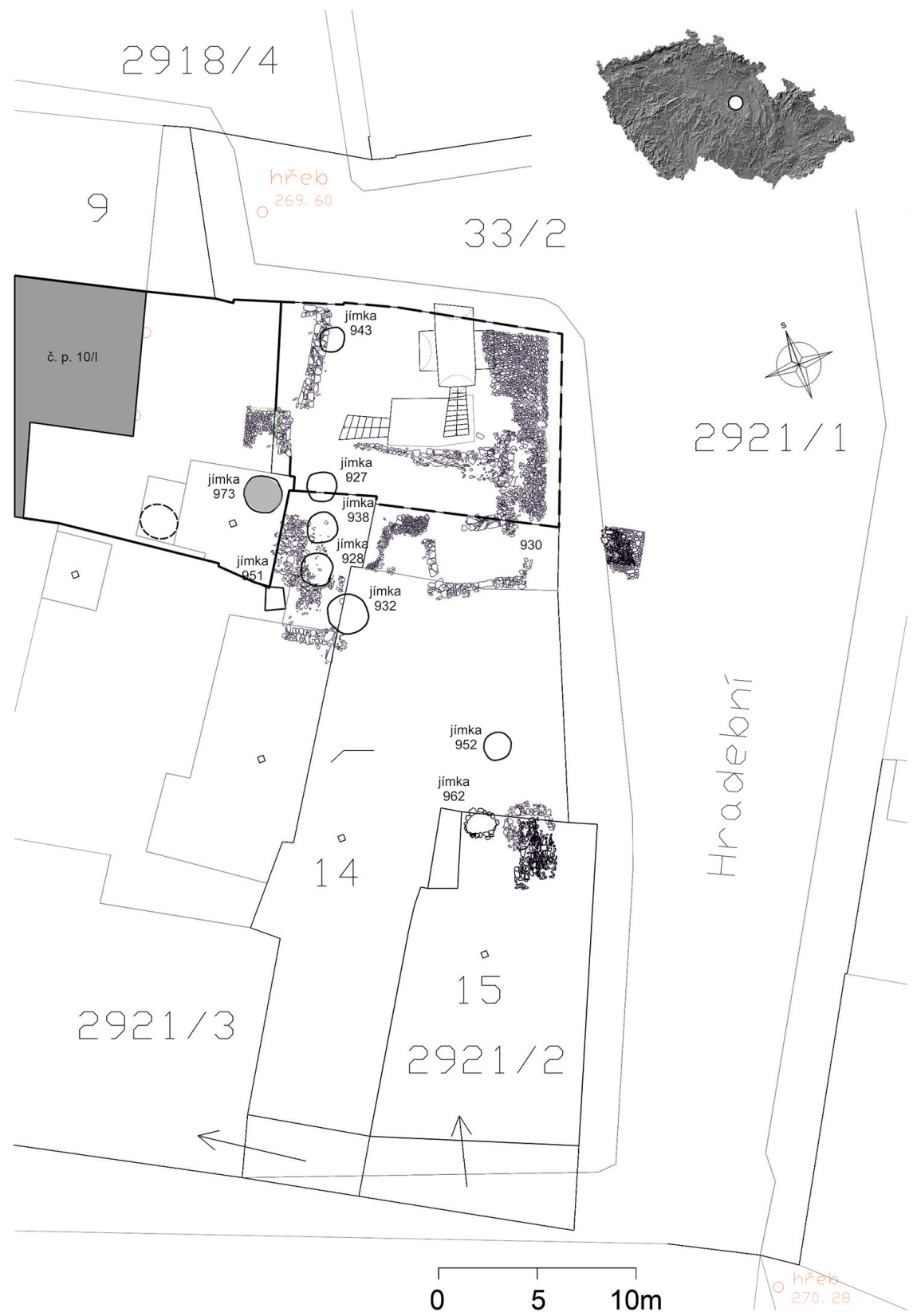

Obr. 1. Chrudim, Hradební ulice. Celkový plán výzkumu v roce 2006 s vyznačením polohy jímky 973 (zvýrazněna šedou barvou). Čárkovaný ovál představuje depresi po doposud nezkoumané střredověké jímce. Silnou černou linií je zvýrazněna hranice parcely domu čp. 10/I (tmavě šedá plocha). Čárkovanou silnou linií je zvýrazněno rozšíření parcely po tř̌icetileté válce. Podklad GEO.CZ, upravili J. Frolík a J. Musil.

Abb. 1. Chrudim, Hradební-Straße. Gesamtplan der Grabung von 2006 mit eingezeichneter Lage von Grube 973 (grau hervorgehoben). Das gestrichelte Oval stellt die Vertiefung einer bislang nicht untersuchten mittelalterlichen Grube dar. Die fette schwarze Linie ist die hervorgehobene Grenze der Parzelle von Haus Konskriptionsnr. 10/I (dunkelgraue Fläche). Die fette gestrichelte Linie ist die hervorgehobene Vergrößerung der Parzelle nach dem Dreißigjährigen Krieg. Vorlage GEO.CZ, Bearbeitung J. Frolík und J. Musil. 


\section{Písemné prameny}

Stejně jako u jiných dosud publikovaných vrcholně středověkých souborů a objektů z výzkumu v Hradební ulici přináší konfrontace s písemnými prameny více otázek než odpovědí. Zkoumaná plocha i celý domovní blok se nacházely ve čtvrti, která byla v soudobých písemných pramenech označena jako Klášterská a později Bohatá. Písemné prameny pro tuto čtvrt', především městské knihy, jsou však dochovány až od 16. a 17. století, čímž se převážně míjejí s chronologií posuzované jímky. Informace o životě zdejších obyvatel ve starším období může poskytnout pouze archeologie.

Domovní blok tvořilo až do třicetileté války celkem osm domů. V době výzkumu stály již jen třri (čp. 9/I, 10/I a čp. 11/I, které spojilo původní nemovitosti čp. 11/I až 13/I). Po třicetileté válce zůstaly stát zřejmě pouze dva domy (čp. 11/I a 13/I). Zpustlá městiště prodávala obec $\mathrm{k}$ obnovení, a tento proces se protáhl až do první čtvrtiny 18. století (dům čp. 15/I v roce 1711).

Dům čp. 10/I se poprvé připomíná až v roce 1705 právě v této souvislosti. Obec prodala pusté místo za pivovarem zemřelého Václava Píseckého Danielu Maršálkovi, ,aby dům zpưsobný od kamene vyzdvihnouti na témž místě povolen byl“, za 5 kop míšeňských s tím, že se nemovitost osvobozuje na tři roky od daní. Pokud by dům nebyl do té doby postaven, nezíská majitel várečné právo. Jakub Maršálek vlastnil nově postavený dům až do roku 1734, kdy ho prodal za 305 zlatých rýnských Heleně Hlavové. Její potomek František Hlava a Anna Markociusová prodávají v roce 1755 dům Janu Geblovi (Köblovi, Göblovi) za 1000 zlatých rýnských. Nový majitel dům ztratil v dražbě v roce 1763, kdy ho získal Václav Beneš. V roce 1778 byl prodán Janu Kroupovi (za stejnou cenu jako $\mathrm{v}$ roce 1755), který v domě provozoval řeznictví (doloženo v roce 1794). Teprve v roce 1809 se poprvé připomíná zahrádka (,varní di̊m se zahrádkou“), na níž původně stál výše zmíněný dům zaniklý za třicetileté války (Frolík-Musil 2010, 12; historické údaje podle Florián s. d.). Zaznamenaný přehled majitelů nepřináší informace o stavební podobě nemovitosti a jejím vybavení. Navíc se časově míjí s nálezy vyzdviženými z jímky 973.

\section{Terénní situace}

Sektor $\mathrm{C} 1$, v němž se posuzovaná jímka nachází, byl situován u západního okraje zkoumané plochy (obr. 1), který byl zkoumán až v závěrečné fázi výzkumu. Terénní situace překrývající jímku byla velmi jednoduchá (obr. 2-3). Pod recentním povrchem z betonových dlaždic se nacházely dvě novodobé uloženiny $\mathrm{C} 1 / 101$ a $\mathrm{C} 1 / 102$ charakteru planýrek o celkové mocnosti až $0,4 \mathrm{~m}$. Spodní uloženina nasedala bezprostředně na horní okraj obezdění jímky. Jímka kruhového půdorysu byla zahloubena do sprašového podloží (uloženina C1/146). Obezděna byla lomovým zdivem z opuky spojovaným hlínou (okrová spraš). Dochovaná, zřejmě úplná výška obezdění činila 3,8 m. Další metr hloubky nade dnem byl vyhlouben do podloží bez obezdění. Průměr jímky kolísal mezi hodnotami 1,6 a 1,9 m. Jímka měla ploché a rovné dno. Objem činil přibližně $12 \mathrm{~m}^{3}$. Výplně jímky byly zkoumány po přirozených terénních vrstvách. Z výplní při bázi jímky byly odebírány vzorky pro prŕírodovědecké expertizy. Prostředí jímky bohužel neumožnilo vzhledem $\mathrm{k}$ charakteru podloží dochování předmětů z organických materiálů. Jímka byla vyplněna celkem 43 různě mocnými uloženinami $(\mathrm{C1} / 103$ až $\mathrm{C1} / 145)$, které můžeme rozdělit do několika etap. Nade dnem jímky se nacházela uloženina $\mathrm{Cl} / 145$ (rezavý jíl s velkou př́měsí zcela rozloženého dřeva $40 \%$ a uhlíků $-5 \%$ ) o mocnosti až 1,6 m. Její okraje charakteristicky vybíhaly podél stěn jímky směrem vzhůru jako důsledek sesedání výplně. Tato uloženina pravděpodobně původně sestávala z více jiných (minimálně ze dvou) uloženin. Výzkum jímky byl totiž dokončován poslední den vyhrazené lhůty celého výzkumu a termín nebylo možné překročit. Proto byla spodní část výplně vybrána jednorázově s cílem získat celý její nálezově bohatý obsah. Obdobně vyhlížejí také následné uloženiny $\mathrm{C} 1 / 144$ až $\mathrm{C} 1 / 139$ charakteru prachových hlín s př́íměsí dřeva a uhlíků (až $84 \%$ ) o celkové mocnosti jen $0,2 \mathrm{~m}$. Následuje předěl v podobě bělošedého písku, snad izolační vrstva (uloženina $\mathrm{C} 1 / 138$ ). Zaplňování jímky pokračovalo uloženinami o celkové mocnosti jen 


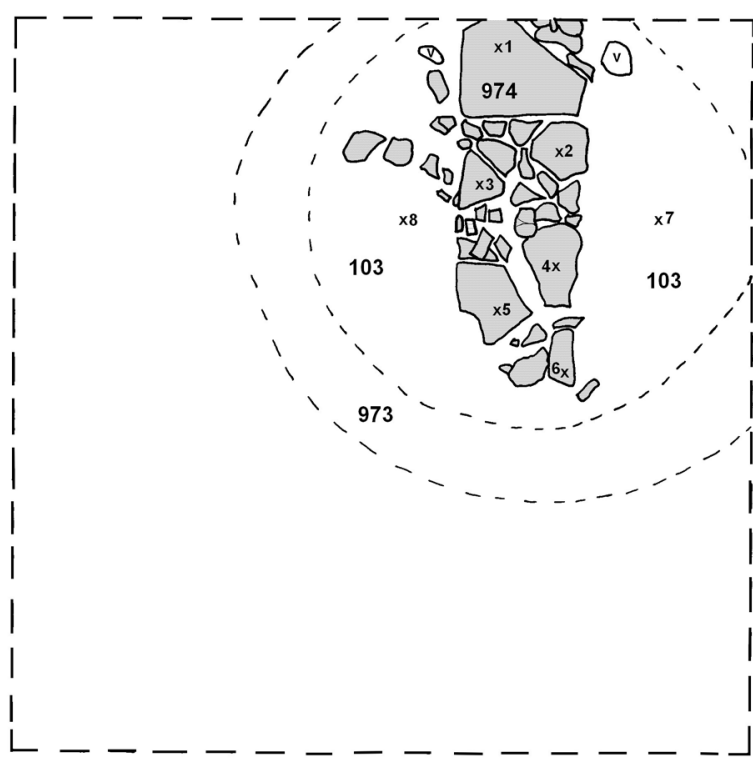

A

0

$1 \mathrm{~m}$

C1 1 D1

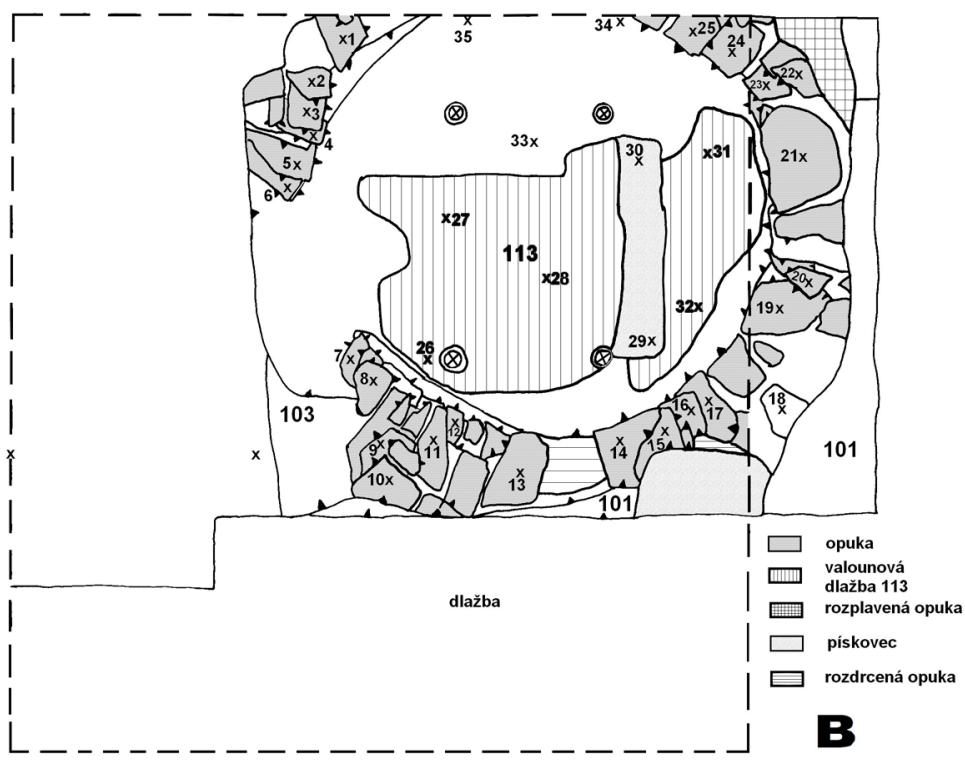

Obr. 2. Chrudim, Hradební ulice, sektor C1. A - půdorys se zdí 974, prosedlou do výplně jímky; B - půdorys jímky 973 v úrovni uloženiny C1/113 (valounová dlažba, pískovcový blok). Digitalizace J. Musil.

Abb. 2. Chrudim, Hradební-Straße, Sektor C1. A - Grundriss mit Mauer 974, in die Verfüllung der Grube abgesunken; B - Grundriss von Grube 973 auf Niveau von Ablagerung C1/113 (Geröllpflaster, Sandsteinblock). Digitalisierung J. Musil. 
$0,1 \mathrm{~m}$ s mírně změněným charakterem (jílovité vrstvy s př́iměsí písku, ale i mazanice a malých fragmentů malty - uloženiny $\mathrm{C} 1 / 137$ až $\mathrm{C} 1 / 131)$. Další změnu ve složení vykazovaly uloženiny $\mathrm{C} 1 / 130$ až C1/126 (celková mocnost až $0,6 \mathrm{~m}$ ) charakteru stavební destrukce s velkým obsahem písku a různorodých kamenů. Objevuje se i cihla (uloženina C1/127). Souvisí s nimi také uloženina $\mathrm{C1} / 133$ na bázi této části výplně, sestávající z valounů a jílu, snad rozebraná a přemístěná dlažba. Shora tvoří předěl až $0,2 \mathrm{~m}$ silná uloženina s velkou př́íměsí uhlíků, možná stopa požáru $(\mathrm{C} 1 / 123)$. Následuje opět nárůst charakteru odpadní výplně (uloženiny C1/122, C1/124 a C1/125, celková mocnost $0,2 \mathrm{~m}$ ) písčitého charakteru a s typickým uprostřed prosedlým průběhem. Jednoznačným dokladem požáru v okolí je uloženina $\mathrm{C} 1 / 121$ tvořená mazanicí $(60 \%)$ a jílem.

Nad touto vrstvou se podoba výplně mění. Zmíněnou uloženinu $\mathrm{C} 1 / 121$ překrývají uloženiny $\mathrm{C} 1 / 116$ až $\mathrm{C} 1 / 120$ charakteru izolace (písčitý jíl s příměsí opukových kamínků (celková mocnost až $0,5 \mathrm{~m})$. Překrývají je dvě písčité uloženiny s velkou př́íměsí oblázků (C1/114 a C1/115), které tvoří podsyp valounové dlažby (C1/113, celková mocnost i s podsypem až $0,6 \mathrm{~m}-$ obr. $2 \mathrm{~B})$.

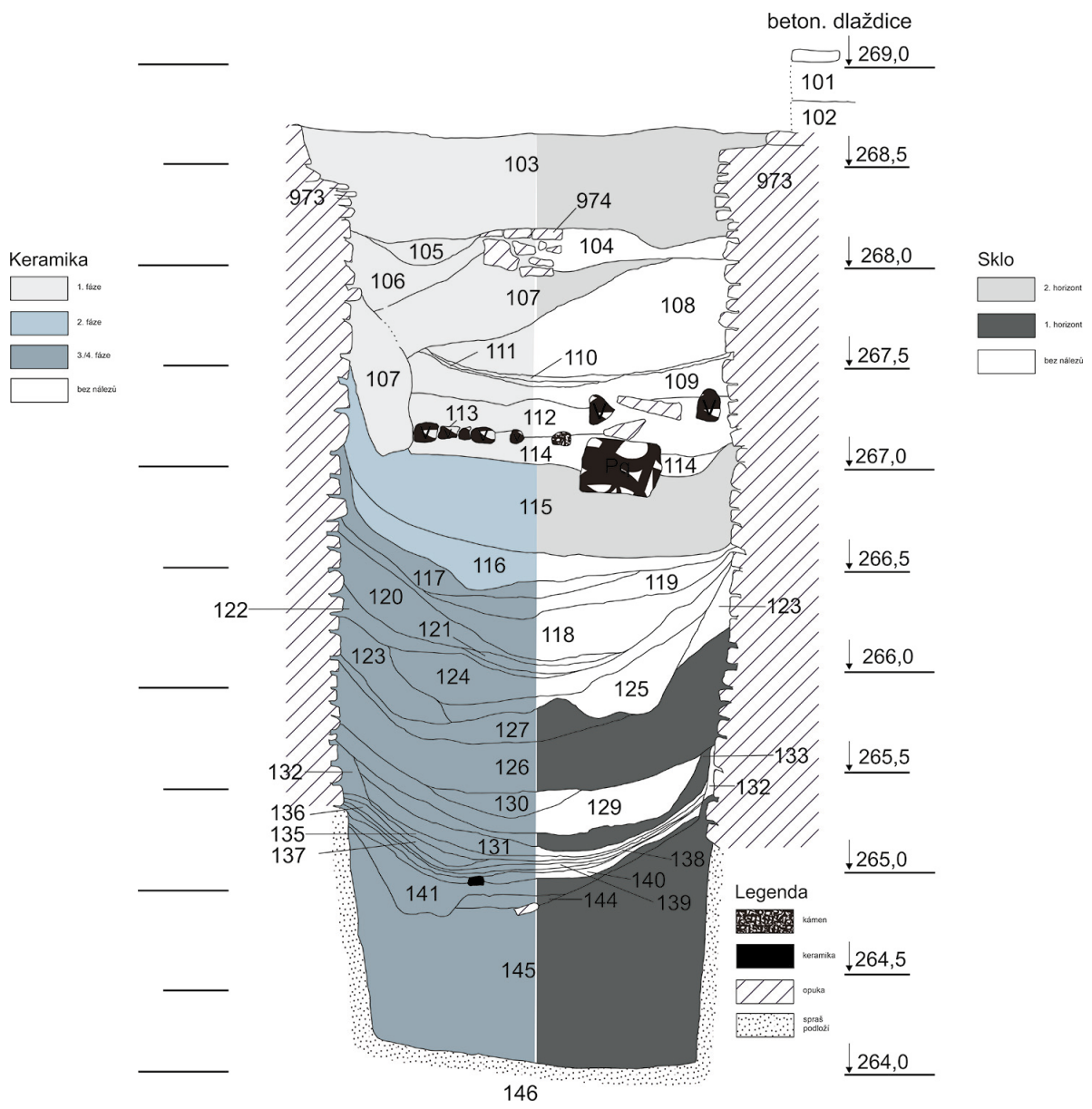

Obr. 3. Chrudim, Hradební ulice, sektor C1. Řez jímkou 973 s vyznačením jednotlivých horizontů zaplňování na základě rozboru souboru keramiky a skla. Vyhotovil J. Musil.

Abb. 3. Chrudim, Hradební-Straße, Sektor C1. Profil von Grube 973 mit Kennzeichnung der einzelnen Verfüllungshorizonte auf Grundlage der Analyse des Keramik- und Glaskomplexes. Erstellt von J. Musil. 


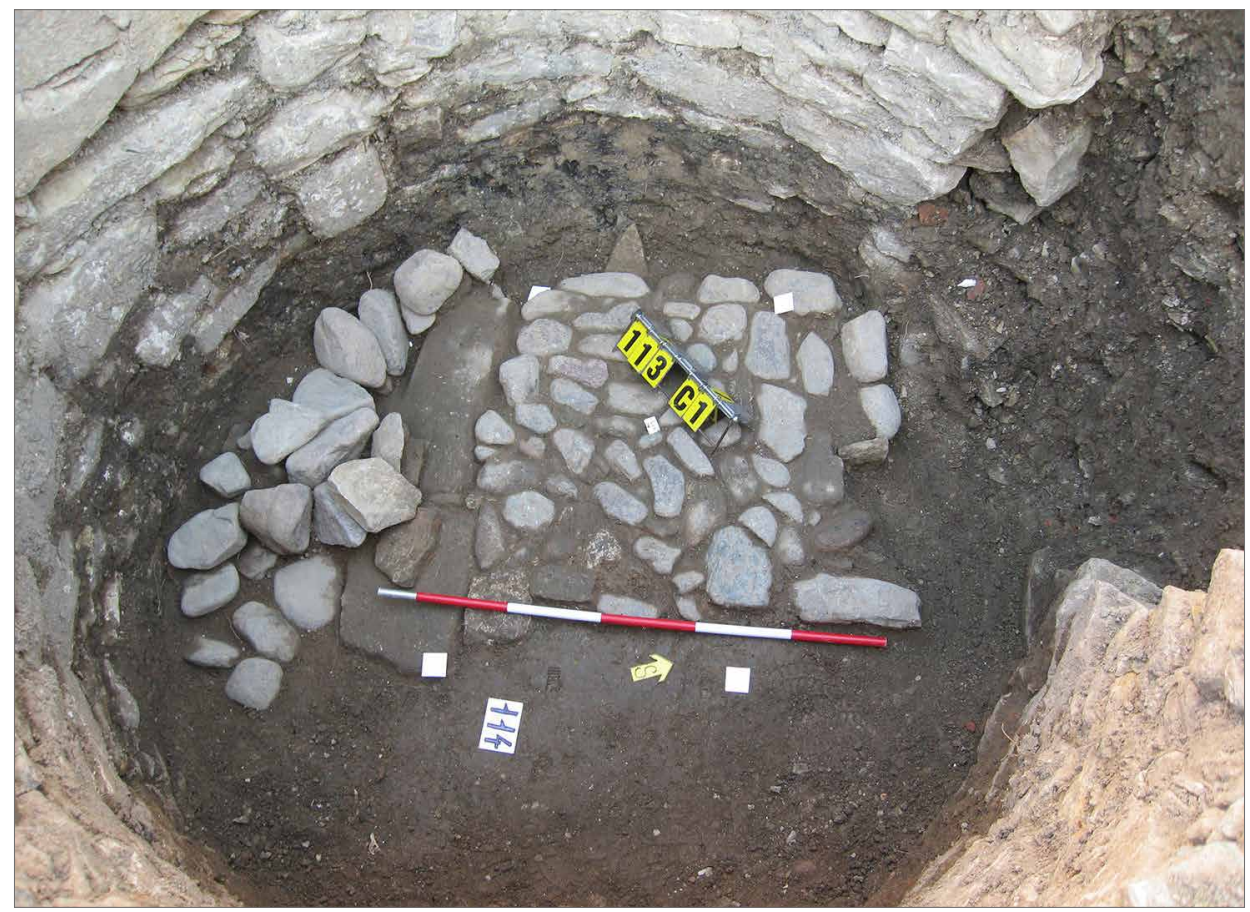

Obr. 4. Chrudim, Hradební ulice, sektor C1. Půdorys jímky 973 v úrovni uloženiny C1/113 (valounová dlažba, pískovcový blok). Foto Osina ARCHEO.

Abb. 4. Chrudim, Hradební-Straße, Sektor C1. Grundriss von Grube 973 auf Niveau von Ablagerung C1/113 (Geröllpflaster, Sandsteinblock). Foto Osina ARCHEO.

Uloženina $\mathrm{C} 1 / 115$ je také poslední, která vybíhá podél stěn jímky vzhůru jako doklad sesedání výplně. Součástí dlažby $\mathrm{C} 1 / 113$ je také rozměrný pískovcový opracovaný blok s dochovanou částí gotické profilace (rozměry $0,95 \times 0,40 \times 0,30 \mathrm{~m}$ ) ve směru východ-západ (obr. $2 \mathrm{~B}$, obr. 4 ). Nad dlažbou se charakter výplně znovu mění. Vrstvy mají převážně vodorovný průběh nebo je možné rozeznat, že byly do jímky sypány z jedné strany. Rozdělit je můžeme na tři části. Bezprostředně nad dlažbou $\mathrm{C} 1 / 113$ se nacházely písčitojílovité hlíny s př́iměsí opukových kamenů, mazanice a fragmentů malty $(\mathrm{C} 1 / 109, \mathrm{C} 1 / 111$ a $\mathrm{C} 1 / 112$, mocnost až $0,45 \mathrm{~m})$, které jsou odděleny od výše zjištěných vrstev uhlíkovým proplástkem $(\mathrm{Cl} / 110)$, snad stopou požáru. Nad ní se uložily vrstvy stavebního odpadu (prachové hlíny s příměsí opuky, mazanice, zlomků cihel a fragmentů malty, uloženiny $\mathrm{C} 1 / 104$ až $\mathrm{C} 1 / 108)$. Do povrchu této části souvrství o mocnosti až $0,75 \mathrm{~m}$ byla zahloubena nasucho kladená zídka z opukových kamenů ve směru východ-západ (zed' 974, délka $1,5 \mathrm{~m}$, šířka $0,55 \mathrm{~m}$ - obr. 2A). Zbývající část výplně jímky až k okraji obezdění (zed' 973) tvořila uloženina $\mathrm{C} 1 / 103$ opět charakteru stavebního odpadu (mocnost až $0,55 \mathrm{~m}$ ).

Výplň jímky 973 můžeme rozdělit na několik částí. Spodní (až do úrovně uloženin C1/116 až $\mathrm{C} 1 / 120$ ) tvoří pro jímky charakteristický odpad z přilehlé parcely/domácnosti. Zaplňování zř̌jmě neprobíhalo lineárně (vrstva izolace $\mathrm{C1} / 138$ ) a obsahuje doklady stavební činnosti (přestavby nemovitosti - uloženiny $\mathrm{Cl} / 126$ až $\mathrm{Cl} / 130$ a C1/133). Př́tomnost fragmentů malty a zlomků cihel dokládá zděnou zástavbu. Mazanice ve větším množství (uloženina $\mathrm{C} 1 / 121$ ) a uloženina s četnými uhlíky $(\mathrm{Cl} / 123)$ signalizují požár, při kterém okolní zástavba vyhořela. Následně se mění také výplň jímky. Do písčitých uloženin byla položena valounová dlažba a rozměrný pískovcový druhotně použitý architektonický článek (obr. 2B a 4). Podle analogické situace z jiných jímek (např. jímka 932 - Kozáková-Klikarová-Frolík 2010, obr. 6; Frolík-Kozáková-Musil 2018, 457, 
482) se dlažba původně nacházela na tehdejším povrchu a překryla zaplněnou jímku. Pískovcový blok mohl být základem nějaké lehčí stavby. Průběh jednotlivých uloženin ukazuje, že tato část terénní situace se postupně prosedala do jímky $\mathrm{v}$ důsledku sesedání starších částí výplně. Na dvorku vznikala deprese, která byla (zdá se, že nadvakrát) vyplněna zavážkami $(\mathrm{C} 1 / 109$ až $\mathrm{C} 1 / 112$ a C1/104 až C1/108). Postupně sesedání terénu v jímce po položení dlažby činilo až $1,7 \mathrm{~m}$. Okraj jímky přesáhla poslední část podobné výplně (uloženina C1/103).

Jímka 973 tvoří jediný vrcholně středověký objekt zkoumaný na současném dvorku domu čp. 10/I. Zbytek se nacházel mimo plochu výzkumu a zkoumáno nebylo ani souvrství, do něhož byla jímka zahloubena. Výpověd' terénní situace tak zůstává limitovaná. Do doby před nejstaršími písemnými zmínkami můžeme pravděpodobně položit jednu přestavbu nemovitosti na parcele, následovanou (s odstupem?) požárem. Po další obnově již nebyla jímka používána a dále se projevovala jen pomalým, ale stálým sesedáním výplně, které jistě komplikovalo provoz na nevelkém dvorku. Za zmínku stojí fakt, že v současné dochované ploše dvora za čp. 10/I se zřetelně rýsuje konkávní prohlubeň po další jímce kruhového půdorysu, která náležela k parcele původního středověkého domu.

\section{Nálezy}

\subsection{Keramika}

Nálezy keramiky představují nejhojněji zastoupený chronologicky dostatečně citlivý archeologický materiál. Celkem bylo vyhodnoceno 6552 ks keramických nádob a jejich zlomků o celkové hmotnosti $150,4 \mathrm{~kg}$. Z tohoto počtu bylo možno vyhodnotit 446 celých nádob a jejich rekonstruovatelných torz. Keramiku lze na základě makroskopicky postižitelných vlastností1 rozčlenit do 53 základních keramických technologických tř́íd (dále jen KT), které mají rovněž chronologický význam (viz graf 1; Frolík-Musil-Sigl s. d.). Jejich datování je založeno na dlouhodobém komparativním studiu opírajícím se jak o dobře datovatelné stratigrafické sekvence z chrudimského městského jádra (Štěpánkova ul., čp. 85/I; Filištínská ul., čp. 37/I - 42/I; Hradební ul., čp. 14/I a 15/I ad.), tak i o lokality s jednoznačně vymezitelným intervalem fungování (např. benediktinský klášter v Podlažicích vypálený husity v dubnu 1421). Celkem 349 zlomků (KT 001 a KT 002) o celkové hmotnosti 7083 g nebylo možné vzhledem ke stavu jejich dochování

Hmotnost KT v rámci horizontů v g

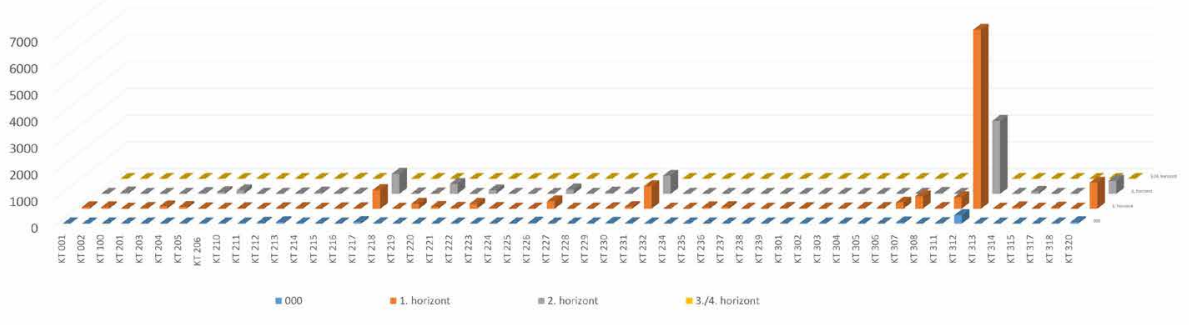

Graf 1. Hmotnost (v gramech) keramických technologických skupin v rámci jednotlivých horizontů jímky 973.

Diagramm 1. Masse (in Gramm) der technologischen Keramikklassen im Rahmen der einzelnen Horizonte von Grube 973.

1 Jsou to: 1) barva, 2) ostřivo, 3) barva lomu, 4) výpal, 5) povrch, 6) afinita s jinými technologickými skupinami. 
blíže zařadit. Díky značnému objemu dat bylo pro účely tohoto př́íspěvku rezignováno na detailní rozbor jednotlivých morfologických a výzdobných prvků, jaký byl podán např́klad při zpracování jímky 962 (Frolík-Kozáková-Musil-Vad’urová 2020). Souhrnné vyhodnocení keramických nálezů z jímky 973 bude podáno $\mathrm{v}$ samostatné studii. V tomto př́spěvku se omezíme pouze na stručnou charakteristiku popisovaného souboru v kontextu s dalšími materiálovými skupinami nálezů.

Na základě analýzy souboru keramiky z jímky 973 byly vyčleněny tři základní časové horizonty (obr. 3), které v zásadě odpovídají již dřive publikovaným souborům z jímek 938 a 962 objevených v Hradební ulici (srov. Frolík-Kozáková-Musil 2018; Frolík-Kozáková-Musil-Vad’urová 2020). Svrchní horizont (označený jako 1. fáze - obr. 5 a 6) obsahující uloženiny (odshora: $\mathrm{C} 1 / 103$, C1/105, C1/106, C1/107, C1/108, C1/110, C1/111, C1/109, C1/112, C1/113 a C1/114) je datován dle nalezených keramických zlomků do 17.-18. století a odpovídá horizontu výklizů domácností zaniklých v průběhu třicetileté války a jejich následné obnovy (srov. kap. 2). V horních partiích výplně jímky je keramika více fragmentarizovaná, chronologicky často velmi nesourodá, výplně jímky se blíží charakterem přemístěné suti (srov. kap. 3). Zhruba od úrovně uloženiny C1/109 se setkáváme s méně fragmentarizovaným keramickým souborem. Keramika je převážně oxidačně pálená, na lomu se střepem bělošedé, oranžové a žlutookrové barvy (KT 312, 1195 ks, 6712 g). Keramické zboží je částečně opatřeno převážně transparentními žlutými, hnědými, žlutozelenými a zelenými polevami, popřípadě jejich kombinacemi. Dále je výrazně zastoupeno i zboží režné, a to jak redukční (KT 217, 108 ks, 698 g), tak i oxidační (KT 231, 91 ks, 842 g; KT 320, $90 \mathrm{ks}, 972 \mathrm{~g})$. Základní keramické tvary představují různé velikostní varianty hrnců s uchem, $\mathrm{s}$ výdutí posunutou směrem $\mathrm{k}$ dolní třetině, dále to jsou džbány s nálevkovitě rozevřeným ústím, často s výzdobou promačkávanou do formiček (obr. 5:9), mísy s talířovým podokrajím (obr. 6), trojnožky s téměř uzavřeným držadlem ad. V př́ípadě mís s talířovitým podokrajím a džbánů zjišt'ujeme aplikaci malovaného dekoru pomocí kukačky (KT 307, 37 ks, 458 g). Z hlediska motiviky se setkáváme převážně s vegetabilními, zoomorfními (jelen, ptáčci) a prostými liniovými motivy. V menší míře se objevuje mramorování a trasakování. Nápadné jsou zejména modře glazované zlomky s proškrabávanou výzdobou (obr. 6; KT 306, 12 ks, 226 g) z okruhu jindřichohradecké mezzomajoliky (Štajnochr-Fröhlich-Krajíc-Militký 1998, 445-468; Fröhlich 2015, 836).

Luxusní importované zboží je dále zastoupeno zlomky saské a lužické kameniny z okruhů Waldenburg, Bad Muskau a Triebel (obr. 5:2-8; KT 225, 1 ks, 4 g; KT 301, 6 ks, 15 g; KT 302, 1 ks, 3 g - srov. Horschik 1978, 295-364). Celé tvary nebyly nalezeny. Jak již bylo konstatováno výše, jedná se pravděpodobně o předměty pocházející z výklizů domácností zaniklých za třicetileté války. Nádoby z kameniny, zejména džbány, byly v domácím prostředí hojně napodobovány (srov. Scheufler 1972, 52-53, 57-60, 62). V našem prostředí se vyskytují přímé napodobeniny mužakovské kameniny s tmavě hnědou transparentní glazurou (KT $303,1 \mathrm{ks}, 5 \mathrm{~g}$ ), popř́ípadě jsou napodobovány výzdobné motivy běžné např́klad u soudobé porýnské kameniny v podobě promačkávání stěny nádoby do drobných formiček se silně abstrahovaným vegetabilním motivem (obr. 5:9). Za zmínku také stojí přítomnost přepáleného středočeského bíle malovaného zboží (obr. 5:1; KT 223, 1 ks, 21 g), které spadá do období 15. a 16. století. Hojněji je tato keramika zastoupená v 3./4. horizontu (viz níže). Zajímavým nálezem je miniaturní hrnek z jemné plavené hlíny (obr. 5:10), který můžeme s největší pravděpodobností interpretovat jako dětské nádobíčko. Pouze stopově bylo zastoupeno novověké keramické zboží datovatelné převážně do 18 . století (KT 304, 305, 306, 308, 314 a 317 - viz graf 1). Intruzi v tomto př́ípadě představují zlomky raně středověké (KT 201, 203, 204 a 205) a vrcholně středověké keramiky (KT 210, 212, 213, 215, 216, 219-222, 225, 226, 228-230, 235, 236 a 239 - viz graf 1).

Změna ve složení keramického souboru byla registrována na úrovni uloženin $\mathrm{C} 1 / 115$ a C1/116, kde byl vymezen přechodný horizont, označený jako 2. fáze (obr. 7; srov. Frolík-Kozáková-Musil 2018, 460-461, obr. 3), datovaný do 16.-17. století. Zde se ještě v menší míře uplatňovalo režné redukční keramické zboží (obr. 7:1,2,4), nicméně většina keramiky náležela oxidačně pálenému (KT 320, 66 ks, 485 g), částečně transparentně glazovanému zboží, na lomu se střepem 

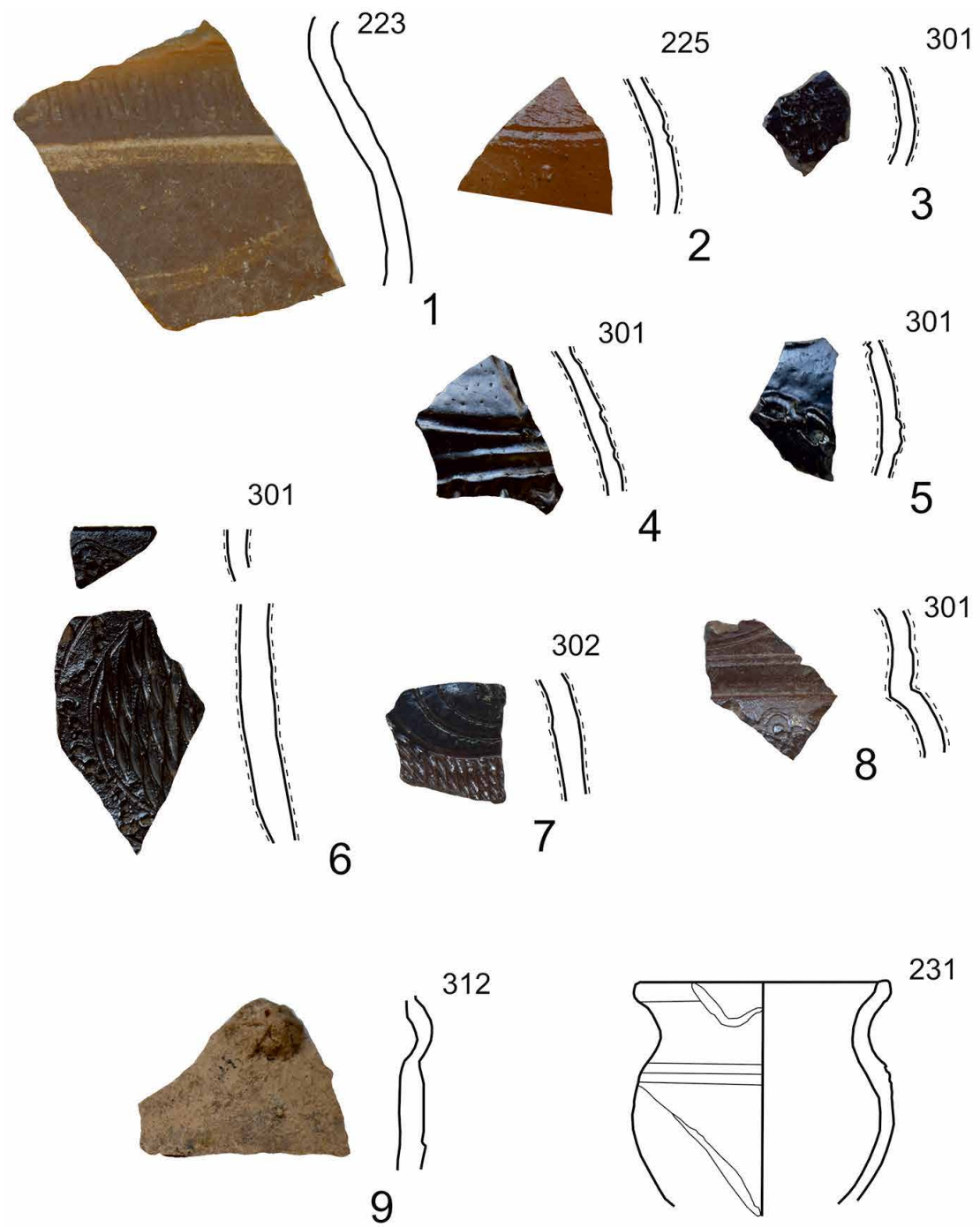

231

10

0

Obr. 5. Chrudim, Hradební ulice, jímka 973. Výběr keramiky 1. horizontu. 1 - červené bíle malované zboží; 2-8 - kamenina; Bad Muskau, Triebel, Waldenburg; 9 - zlomek zdobený promačkáváním stěny do formičky; 10 - dětské nádobičko. Trojmístné číslo odpovídá konkrétní keramické technologické tř́iě. Kresba J. Musil.

Abb. 5. Chrudim, Hradební-Straße, Grube 973. Keramikauswahl des 1. Horizonts. 1 - rote weiß bemalte Keramik; 2-8 - Steinzeug; Bad Muskau, Triebel, Waldenburg; 9 - durch Eindrücken der Wandung in eine Form verziertes Bruchstück; 10 - kleines Kindergefäß. Die dreistellige Zahl entspricht jeweils der konkreten technologischen Keramikklasse. Zeichnung J. Musil. 

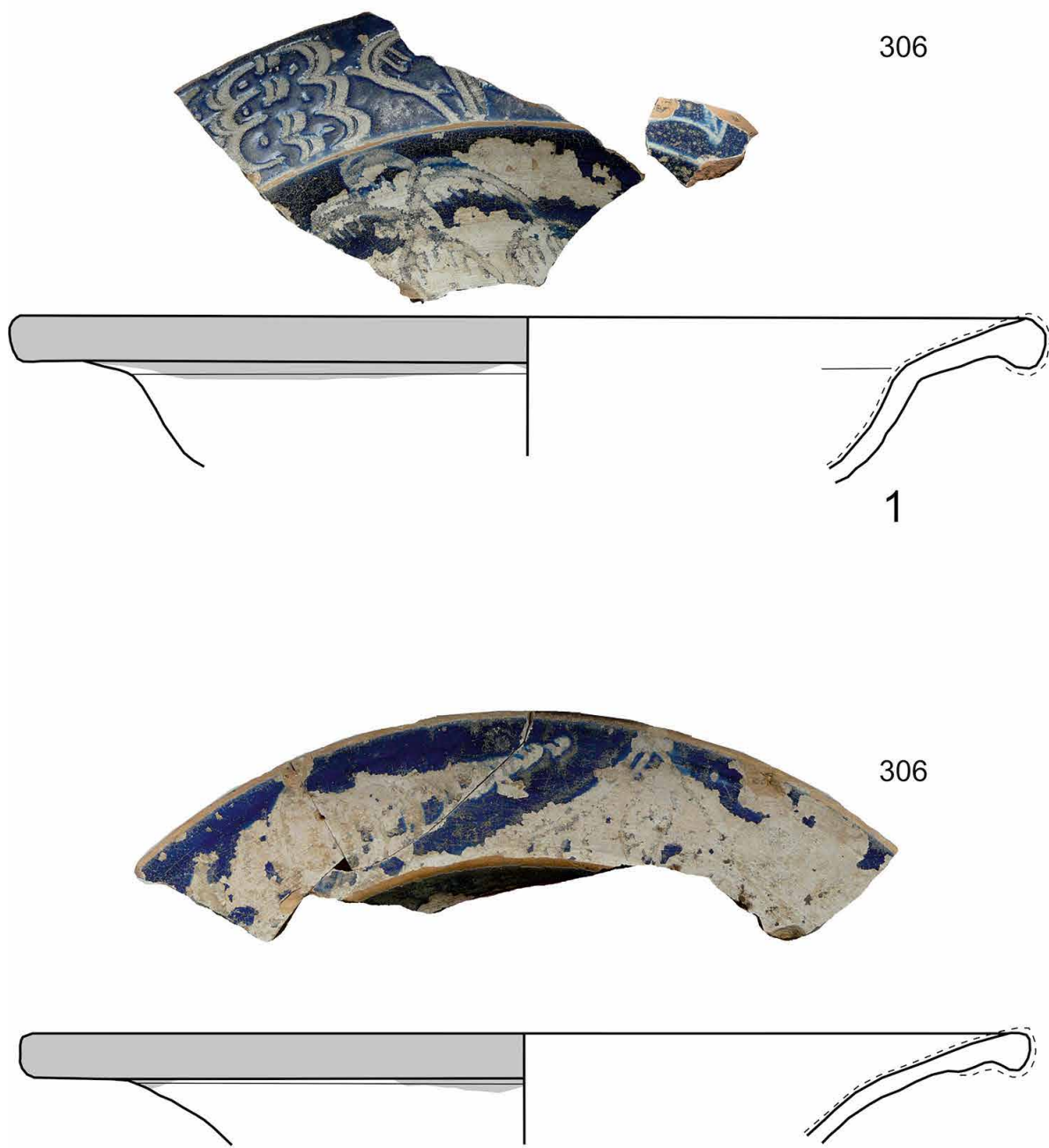

2

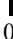

$3 \mathrm{~cm}$

Obr. 6. Chrudim, Hradební ulice, jímka 973. Výběr keramiky 1. horizontu. 1-2 - jindřichohradecká mezzomajolika. Trojmístné číslo odpovídá konkrétní keramické technologické tř́ídě. Kresba M. Sedláčková a J. Musil.

Abb. 6. Chrudim, Hradební-Straße, Grube 973. Keramikauswahl des 1. Horizonts. 1-2 - Neuhauser Mezzo-Majolika. Die dreistellige Zahl entspricht jeweils der konkreten technologischen Keramikklasse. Zeichnung M. Sedláčková und J. Musil. 

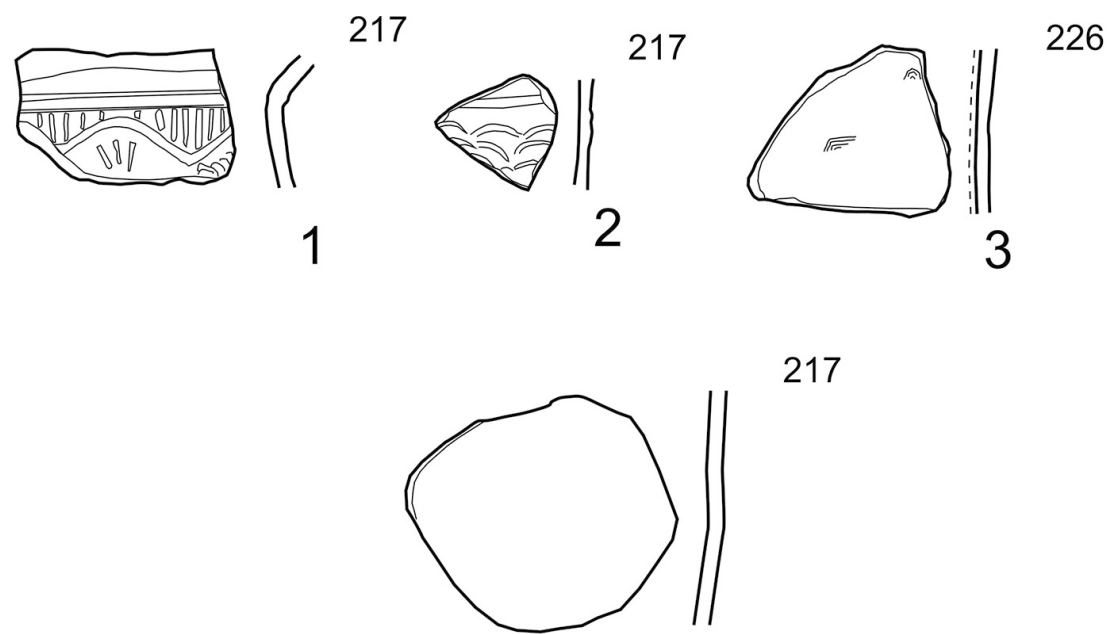

4
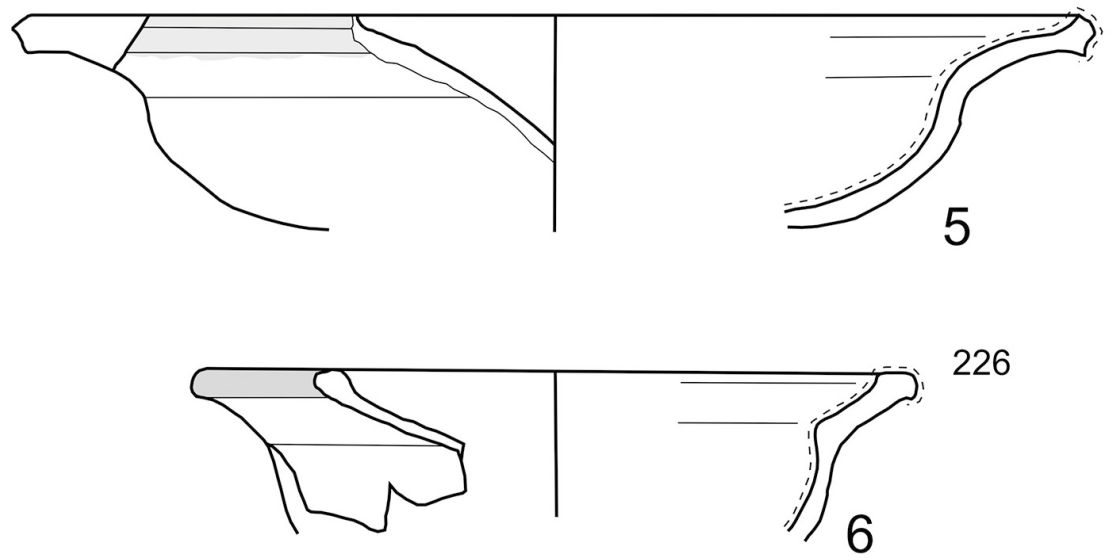

226
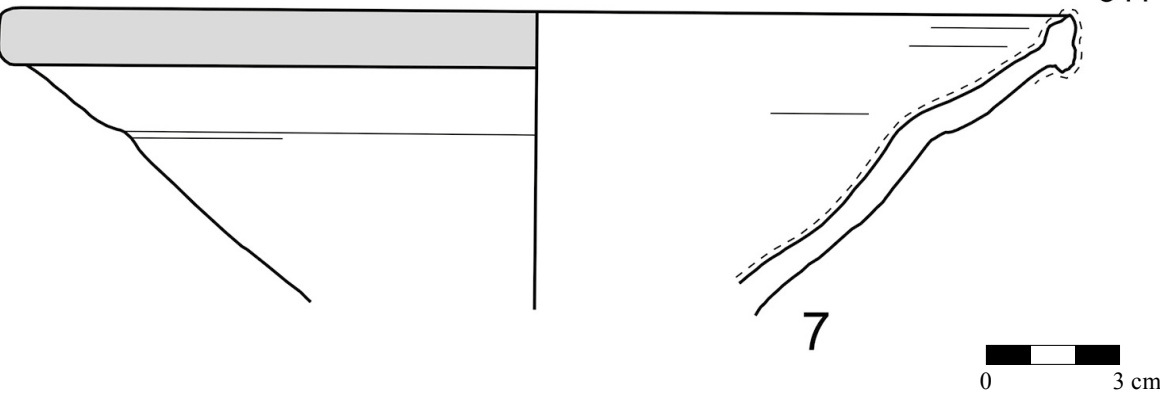

Obr. 7. Chrudim, Hradební ulice, jímka 973. Výběr keramiky 2. horizontu. 1-2 - zlomky redukění keramiky zdobené radélkem; 3-4 - žetony broušené ze střepů; 5-7 - torza mís s talířovým podokrajím. Trojmístné číslo odpovídá konkrétní keramické technologické tř́íě. Kresba M. Sedláčková a J. Musil.

Abb. 7. Chrudim, Hradební-Straße, Grube 973. Keramikauswahl des 2. Horizonts. 1-2 - rädchenverzierte Bruchstücke von Reduktionskeramik; 3-4 - aus Scherben geschliffene Jetons; 5-7 - Schüsseltorsi mit tellerartigem Unterrand. Die dreistellige Zahl entspricht jeweils der konkreten technologischen Keramikklasse. Zeichnung M. Sedláčková und J. Musil. 
bělošedé (KT 312, 512 ks, 2738 g) a oranžové barvy (např. obr. 7:7; KT 311, 84, 388 g), krytému na vnitřní straně nádoby žlutooranžovou transparentní glazurou. Svébytné postavení v rámci tohoto horizontu má místní chrudimské zboží typu Husova ulice částečně kryté hnědočervenou transparentní glazurou (např. obr. 7:5, 6; KT 226, 8 ks, 163 g; Frolík-Sigl 1990; k nastupující raně novověké produkci v Chrudimi - Musil 2010, 21-36). Vyjma hrnců a trojnožek je zastoupeno i mísami s talířovým podokrajím (obr. 7:5, 6). Relativně hojně se objevuje jemné režné oxidační zboží světle oranžových až červených tónů (KT 231, 101 ks, 678 g - srov. graf 1). Mezi zajímavé artefakty patří dva sekundárně zbroušené keramické zlomky. První má zhruba trojúhelníkovitý tvar a připomíná tzv. hrnčířské čepele, druhý nepravidelně oválný snad mohl sloužit nejspíše jako hrací žeton (obr. 7:3, 4), nicméně nemůžeme vyloučit, že se jednalo o polotovar přeslenu.

Na rozdíl od již zpracované jímky 938 (Frolík-Kozáková-Musil 2018) se u jímky 973 nepodařilo spolehlivě zjistit 3 . horizont, kladený do 15 . až 16 . století. Od úrovně uloženiny $\mathrm{C} 1 / 117$ až po bázi jímky registrujeme díky kvalitně provedené dokumentaci a pečlivému laboratornímu zpracování nálezů propadávání částí nádob z horních úrovní až ke dnu jímky. Počítat musíme rovněž $\mathrm{s}$ odstraněním části výplní při čištění jímky ještě v rámci vrcholného středověku. Proto od úrovně $\mathrm{C} 1 / 117$ hovoříme o 3./4. horizontu, zabírajícím široké období od konce 14 . do přelomu 15. a 16. století (obr. 8-11). Ani detailní rozbor provedený v rámci jednotlivých uloženin neumožnil rozpoznat ostřejší kontury jednotlivých chronologických fází, protože i při bázi jímky byly nalezeny předměty odlišných vývojových etap. Proto tedy v rámci tohoto horizontu můžeme sledovat vnitřní vývoj zejména na základě zastoupení jednotlivých keramických technologických tříd (srov. graf 1). S podobnou situací jsme se setkali i v případě jímky 962 (Frolík-KozákováMusil-Vad’urová 2020, obr. 2).

Nejstarší studované zlomky keramiky náleží do pravěkého (KT 100) a raně středověkého období (KT 201, 204-206; základní informace o raně středověké keramice na Chrudimsku srov. Frolík-Sigl 1995). Jedná se o 12 zlomků o celkové hmotnosti 430 g. Na zkoumané ploše registrujeme silné stopy pravěkého a raně středověkého osídlení (Frolík-Musil 2010, 5-6; Novák 2010; Rozsypalová 2010). V sektoru C1 nebyly prímo archeologické terény tohoto stáří registrovány, z čehož vyplývá, že starší nálezy pocházející z výplně jímky představují intruzi.

Nejstarší vrcholně středověká keramika registrovaná v rámci 3./4. horizontu jímky 973 představuje částečně obtáčené zboží tmavě hnědých a hnědošedých tónů (KT 210, 2 ks, 341 g), které je reprezentováno pouze zlomky hrncovitých nádob (více Frolík-Kozáková-Musil-Vad’urová 2020, 450).

Do stejného časového období spadá torzo grapenu zhotoveného z vysoce kvalitní šedé kovově lesklé keramiky s bílým lomem (KT 235, 1 ks, 53 g). Analogické nálezy byly získány z jímky 962 (Frolík-Kozáková-Musil-Vad’urová 2020, 450) a z areálu nedalekého benediktinského kláštera v Podlažicích (Frolík-Musil-Sigl s. d.). Výrobní zónu této keramiky je nutno hledat v německých zemích. Importem je také kovově lesklé zboží s „pravěkou“ úpravou povrchu a červeným lomem (KT 237, 1 ks, 6 g). Analogických nálezů je dosud z území České republiky známo málo, konkrétně z Prahy, Krašovic u Sedlčan, zaniklého středověkého městečka v poloze Sekanka u Davle, Týnce nad Sázavou a Volyně (Hejna 1983, 416). Z východočeského prostoru byly doposud známy pouze zlomky z hradu Rabštejnku (Lacina-Musil 2020, 9).

Pro 14. století je charakteristické převážně vytáčené šedé zboží s kožovitým slídovým přetahem a sendvičovým efektem (KT 212, $92 \mathrm{ks}, 6118 \mathrm{~g}$ ). V rámci 3./4. horizontu je reprezentováno hrnci, zvonovitými pokličkami a džbány (např. obr. 9:5). U hrnců registrujeme okraje jednoduché, ve formě pravého i nepravého okruží, ovalené s vnitřním prožlabením a kyjovité. Jak již bylo řečeno výše, $\mathrm{z}$ technologického hlediska se jedná převážně o keramiku vytáčenou na rychle rotujícím hrnčiřském kruhu, kterou patrně produkovaly městské dílny snad z okruhu Čáslavi, Chotěboře či Ledče nad Sázavou. V ploše bývalého chrudimského okresu se vyskytuje v polygonu mezi Ronovem nad Doubravou, Chrudimí a Skutčí (detailně Frolík-Kozáková-Musil-Vad’urová 2020, 450-451).

Shodně datovatelné je i nápadné světle šedé vysoce slídnaté zboží typu Zbyslavec (KT 232, 24 ks, 4364 g). Toto nezdobené keramické zboží je v souboru zastoupeno hrnci i džbány 


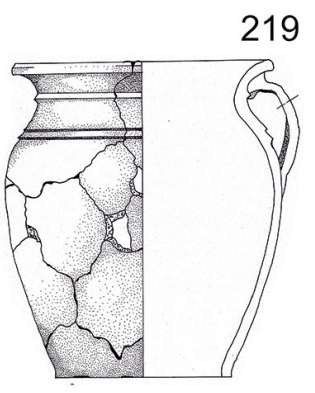

1

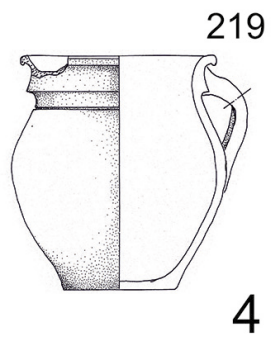

4
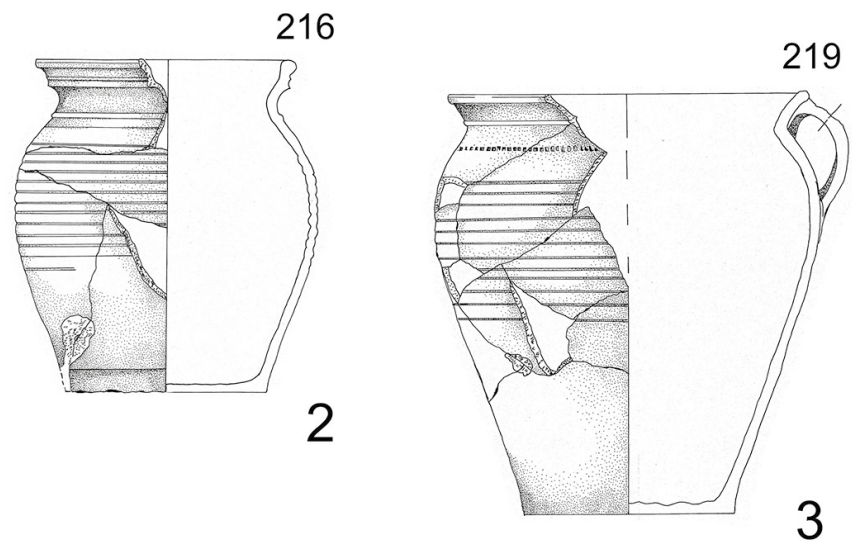

232

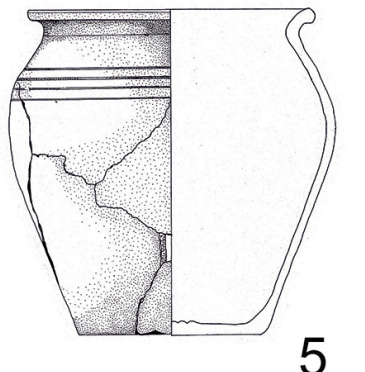

231

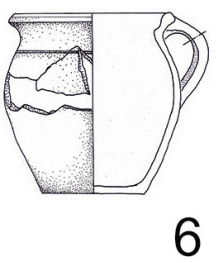

5

218
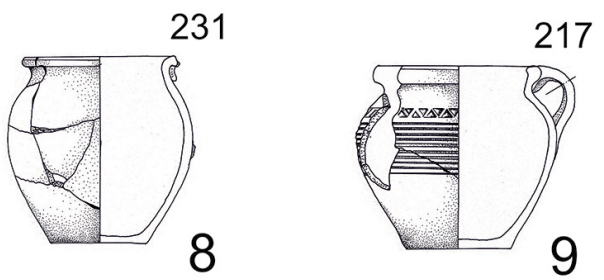

7

8

9

$0 \quad 3 \mathrm{~cm}$

Obr. 8. Chrudim, Hradební ulice, jímka 973. Výběr keramiky 3./4. horizontu - hrnce. Trojmístné číslo odpovídá konkrétní keramické technologické třídě. Kresba B. Hlaváčová, P. Jakubková a K. Holínková.

Abb. 8. Chrudim, Hradební-Straße, Grube 973. Keramikauswahl des 3./4. Horizonts - Töpfe. Die dreistellige Zahl entspricht jeweils der konkreten technologischen Keramikklasse. Zeichnung B. Hlaváčová, P. Jakubková und K. Holínková. 
(obr. 8:5 a 9:7). Zvláštní pozornost si zaslouží zejména džbán zdobený vodorovnou rýhou a ozubeným kolečkem, jehož výdut částečně plošně pokrývá bílá malba (obr. 9:7). Z hlediska profilace sledujeme varianty nepravých okruží, přehnutých oblých i zavinutých okrajů. Podobně jako $\mathrm{v}$ předešlém případě se jedná o vyspělé zboží $\mathrm{z}$ větší části vytáčené na rychle rotujícím hrnčířském kruhu, které patrně produkovaly městské dílny snad z okruhu Čáslavi, Chotěboře či Ledče nad Sázavou. Vyskytuje se v širší oblasti mezi Chrudimí a Ronovem nad Doubravou (Frolík-Kozáková-Musil-Vad’urová 2020, 451; Musil-Netolický-Preusz 2020, Př́íloha 1). Výrazně je zastoupeno částečně obtáčené protoredukční keramické zboží tmavších tónů (KT 230, 109 ks, 3722 g), které registrujeme i na dalších soudobých lokalitách na Chrudimsku (Frolík-KozákováMusil-Vad’urová 2020, 451; Musil-Netolický-Preusz 2020, Př́loha 1). V souboru je zastoupena keramika kuchyňská, reprezentovaná hrnci a pokličkami se zvonovitým tělem. Z hlediska profilace rozpoznáváme okraje jednoduché, různé varianty nepravého i pravého okruží, okraje ovalené s vnitřním prožlabením a okraje přehnuté oblé. Paralelně s ním se na Chrudimsku (Frolík-Kozáková-Musil-Vad'urová 2020, 451; Musil-Netolický-Preusz 2020, Př́iloha 1) vyskytuje nezdobené, tmavé opticky tvrdě vypálené vytáčené keramické zboží (KT 229, 12 ks, 165 g). Obdobně je možno datovat interval výskytu oranžového obtáčeného zboží (KT 221, 12 ks, 4904 g). Z uloženiny $\mathrm{C} 1 / 141$ byl vyzvednut menší hrnec s páskovým prožlabeným uchem a ovaleným okrajem s vnitřním prožlabením (obr. 8:6). Analogické nálezy pochází z jímky 962 v Chrudimi (Frolík-Kozáková-Musil-Vad’urová 2020, 452) a z hradů Rabštejnka (Lacina-Musil 2020) a Košumberka (Musil 2018, 82).

V období druhé poloviny 14. až počátku 15. století se na Chrudimsku (Frolík-Sigl 1998, 116; Frolík-Kozáková-Musil 2018, obr. 8; Frolík-Kozáková-Musil-Vad’urová 2020, 452; Musil-Netolický-Preusz 2020, Př́loha 1) setkáváme se světlým oxidačně vypáleným zbožím s přetaženým krupičkovitým povrchem (KT 218, 274 ks, 15741 g). V souboru z jímky 973 je zastoupena zejména hrnci (obr. 8:7) a tzv. chrudimskými poháry (obr. 10:1-4, 6, 10). Do stejného časového intervalu spadá výskyt velmi kvalitně vypálené keramiky s kožovitým povrchem (KT 219, 89 ks, 4809 g), které se částečně překrývá s okruhem světlé oxidační keramiky zdobené červeným malovaným dekorem (viz níže KT 213). Je zastoupeno hrnci (obr. 8:1, 3, 4) i poháry (obr. 10:8). I toto keramické zboží je na Chrudimsku poměrně rozšiřené (srov. Frolík-Kozáková-Musil-Vad’urová 2020, 452; Musil-Netolický-Preusz 2020, Př́íloha 1). Paralelně se vyskytne i hrubší oxidační zboží (KT 220, 37 ks, 5415 g), které v souboru reprezentují pouze nezdobené zlomky kuchyňské keramiky, zejména kónických mís s vodorovným obloukovitým okrajem. Tuto keramiku nacházíme na řadě soudobých lokalit v prostoru mezi Jezbořicemi, Chrudimí, Novými Hrady a Skutčí (Frolík-Kozáková-Musil-Vad’urová 2020, 452; Musil-Netolický-Preusz 2020, Př́loha 1; Lacina-Musil 2020; Musil 2018, 82; 2020; Frolík-Mácalová-Stránská 2016, 29-34; Frolík 2019, 77-112).

Dislokace výskytu těchto výše popisovaných keramických tříd odpovídá rozložení distribučních zón vymezených v minulosti Pavlem Vařekou (1998, obr. 1), které nedávno graficky vynesl ve svém shrnujícím př́spěvku Ladislav Čapek (2020, obr. 6). Chrudimsko jako takové leží na průniku šesti až sedmi hlavních keramických skupin, což nepochybně souvisí s kř́ižením hlavních spojnic mezi Čechami a Moravou. Plasticky to mimo jiné dokládá i privilegium Vladislava II. Jagellonského pro Chrudim z roku 1486. Výslovně jsou na chrudimském trhu zmiňovány vozy s hrnci z Loštic a z Ledče nad Sázavou (Nekuda-Reichertová 1968, 25; Goš 2007, 96).

Obecně lze říci, že v keramickém materiálu zejména na úrovni uloženin C1/141 až C1/145 je patrný přísun luxusnější importované keramiky, a to jak z našeho území (loštická - obr. 10:9, červeně a bíle malovaná - obr. 14:3, jihlavský pohár - obr. 10:7, tmavě zeleně glazovaná - obr. 10:2), tak i ze zahraničí (glazované balsamarium - obr. 11:4). Dalším průvodním jevem tohoto období je obecně navýšení počtu pohárů (obr. 10) a džbánů (obr. 9). Ačkoliv je tento jev dobře sledovatelný i na jiných místech v Chrudimi (Filištínská ulice, jímky VIIA, VIIB a X - Wolf 2002; obecně sonda H - Horák 2007; jímka XIXB - Sehnoutková 2011), neprojevuje se tak markantně jako u odpadních jímek z Hradební ulice (Frolík-Kozáková-Musil 2018; Frolík-Kozáková-Musil-Vad’urová 2020). 


\section{6}
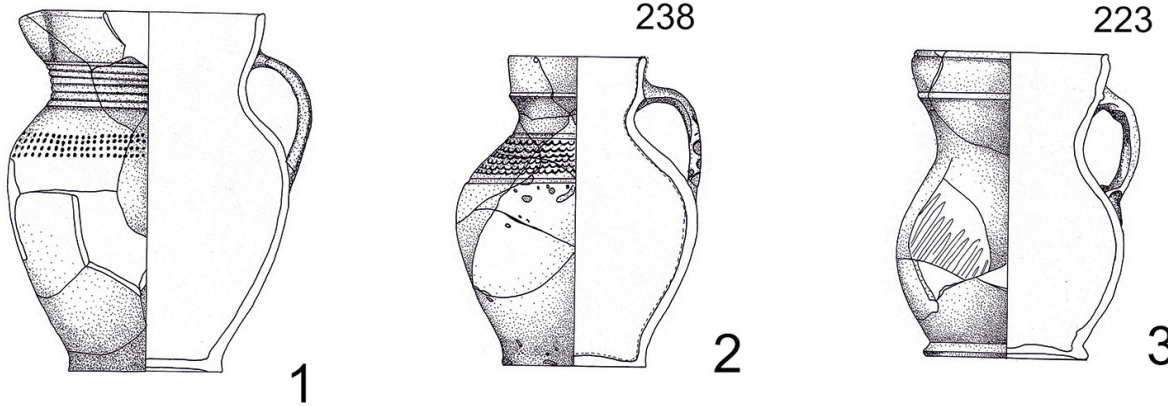

217

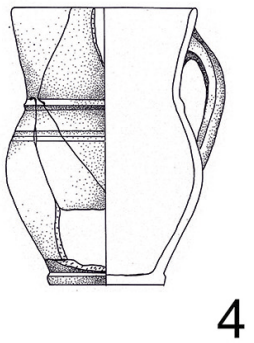

212

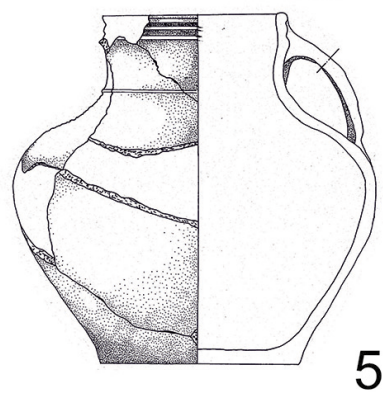

217

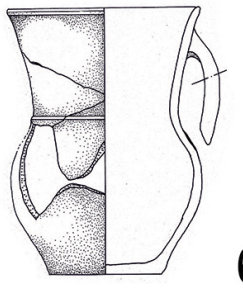

6

5

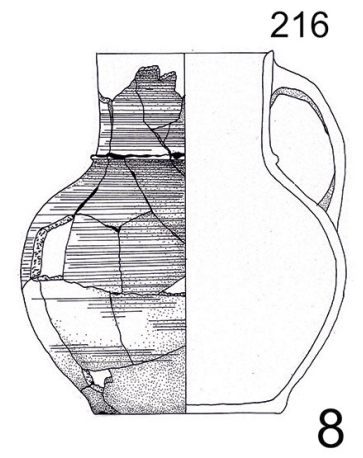

Obr. 9. Chrudim, Hradební ulice, jímka 973. Výběr keramiky 3./4. horizontu - džbány. 1, 4-6, 8 - redukění zboží; 2 - oxidační tmavě zeleně glazované zboží; 3 - okruh světlé červeně malované keramiky; 7 - redukční zboží typu Zbyslavec s bílým plošným nátěrem. Trojmístné číslo odpovídá konkrétní keramické technologické třídě. Kresba B. Hlaváčová, P. Jakubková a K. Holínková.

Abb. 9. Chrudim, Hradební-Straße, Grube 973. Keramikauswahl des 3./4. Horizonts - Krüge. 1, 4-6, 8- Reduktionskeramik; 2 - dunkelgrün glasierte Oxidationskeramik; 3 - Umkreis der hellen rot bemalten Keramik; 7 - Reduktionskeramik vom Typ Zbyslavec mit weißem großflächigem Anstrich. Die dreistellige Zahl entspricht jeweils der konkreten technologischen Keramikklasse. Zeichnung B. Hlaváčová, P. Jakubková und K. Holínková. 
Od konce 14. století sledujeme na Chrudimsku masivní př́liv tmavého redukčního zboží z různých produkčních oblastí (Č́slav, Chotěboř, Ledeč nad Sázavou - Frolík-KozákováMusil-Vad'urová 2020, 452-454; Musil-Netolický-Preusz 2020, Př́loha 1). V našem souboru se projevují celkem čtyři keramické technologické tř́ídy (KT 214-217), které se od sebe liší kvalitou výpalu, použitým ostřivem a úpravou povrchu. Pro období konce 14. a první poloviny 15. století dominuje redukční keramika ostřená pískem (KT 215, 328 ks, 10791 g). V souboru je zastoupena zlomky hrnců, mís (obr. 11:2) a pokliček. Zvláštní pozornost si zaslouží trojboký tzv. jihlavský pohár zdobený pomocí ozubeného kolečka (obr. 10:7). Vyskytuje se na řadě lokalit na Chrudimsku, Skutečsku i v Železných horách (Frolík-Kozáková-Musil-Vad’urová 2020, 452; Lacina-Musil 2020; Musil-Netolický-Preusz 2020, Př́loha 1; Musil 2016; 2020; Frolík 2019, 77-112). Do první poloviny 15. století řadíme vyspělou, na kruhu točenou redukčně vypalovanou hrnčinou s písčitým ostřivem v keramickém těstě (KT 214, 324 ks, 7359 g). Tato keramika patrně souvisí s čáslavskými hrnčířskými dílnami (Frolík-Kozáková-Musil-Vad’urová 2020, 453; Lacina-Musil 2020; Musil-Netolický-Preusz 2020, Př́loha 1; Musil 2014; 2020). Podobně jako v rámci jímky 962 (Frolík-Kozáková-Musil-Vad’urová 2020, 453) i zde v rámci 3./4. horizontu sledujeme výskyt redukčního zboží s kožovitým povrchem (KT 216, 201 ks, 11538 g). Zastoupeny jsou hrnce (obr. 8:2), pokličky a džbány (obr. 9:1, 8). Toto zboží registrujeme v celém Chrudimsku i v Železných horách (Frolík-Kozáková-Musil-Vad'urová 2020, 453; Musil-Netolický-Preusz 2020, Př́iloha 1). Nejrozšířenější skupinou režné redukční keramiky je kovově šedé či černé leštěné keramické zboží (KT 217, 1387 ks, 29962 g), často nesoucí výzdobu provedenou pomocí ozubeného kolečka. Keramika je značně variabilní, dominují zejména hrnce (obr. 8:9) a zvonové pokličky, dále džbány (obr. 9:4, 6) a mísy s jedním či dvěma třmenovými uchy (obr. 11:3). Mezi zvláštní tvary patří tyglíková lampička (obr. 11:5), pravděpodobně z kutnohorské produkční zóny (Bělinová-Musil 2011, 40, pozn. 8). Četné analogie pro toto zboží nalezneme zejména v Čáslavi (Pavlů 1982, obr. 7-10; 1991), v Ledči nad Sázavou (Nechvátal 1967; Chvátal-Rous-Vokáč-Zimola 2013) nebo na hradě Lipnici (Nekuda-Reichertová 1968, obr. 53). Rozsáhlé soubory této keramiky byly publikovány z Chrudimi (srov. Frolík-Kozáková-Musil 2018, 453; Frolík-Kozáková-Musil-Vad’urová 2020, 454) či z hradu Rabštejnka (Musil 2009; 2013; Lacina-Musil 2020), masivně se vyskytuje i na dalších lokalitách (Musil-Netolický-Preusz 2020, Příloha 1; Musil 2021; 2020; 2014; Frolík 2019, 77-112; Musil 2017; Frolík-Stránská-Švédová 2018; Frolík-Mácalová-Stránská 2016, 29-34).

Pouze rámcově do období 14.-15. století můžeme datovat okruh světlé keramiky s červeným malováním (KT 213, 15 ks, 1865 g). Tato ve středověku hojně rozšířená keramika byla současně vyráběna na různých místech naší republiky (Gabriel-Smetana 1983). I toto keramické zboží bylo na Chrudimsku velmi oblíbené (Frolík-Kozáková-Musil-Vad’urová 2020, 452; Musil-Netolický-Preusz 2020, Příloha 1; Frolík 1984, obr. 29; 30:2; 2019, 77-112; Frolík-Mácalová-Stránská 2016, 29-34; Frolík-Stránská-Švédová 2018; Lacina-Musil 2020; Musil 2020; 2016). Podobně tomu je i v př́ípadě zboží severomoravského výrobního okruhu (Goš 1983, 205; 2007; KT 224, 14 ks, 1019 g), které bylo distribuováno po celém Chrudimsku, napříč všemi sociálními prostředími (srov. Frolík-Kozáková-Musil-Vad’urová 2020, 454-455; Musil-Netolický-Preusz 2020, Př́loha 1; Lacina-Musil 2020). Ze stejné produkční oblasti pochází i charakteristické loštické poháry (KT 211, 2 ks, 223 g). Dochovaný exemplář s deformovaným okrajem (obr. 10:9) je možno zařadit pod Měřínského přechodný typ mezi poháry typu IA a IB (Měřínský 1969, tab. III:6). Loštické poháry nalezneme v Chrudimi (Bláha-Frolík-Sigl 2003), v Hlinsku (Frolík 1989, 20), v Chroustovicích, na hradech Oheb (Frolík-Musil-Sigl s. d.), Nové Hrady (tamtéž), Košumberk (tamtéž) a Strádov (Musil 2016).

Pouze obecně do období 14.-15. století můžeme zařadit zlomky oxidačního částečně (KT 227, 1 ks, 4 g) a oboustranně (KT 228, 8, 240 g) žlutě a žlutooranžově transparentně glazovaného keramického zboží. Obdobná situace platí i pro částečně tmavě zeleně transparentně glazované zboží (KT 238, 3 ks, 752 g - srov. obr. 9:2). Nastupující raně novověkou keramickou produkci konce 15 . a první poloviny 16 . století reprezentuje lokální specifické hnědočerveně transparentně 

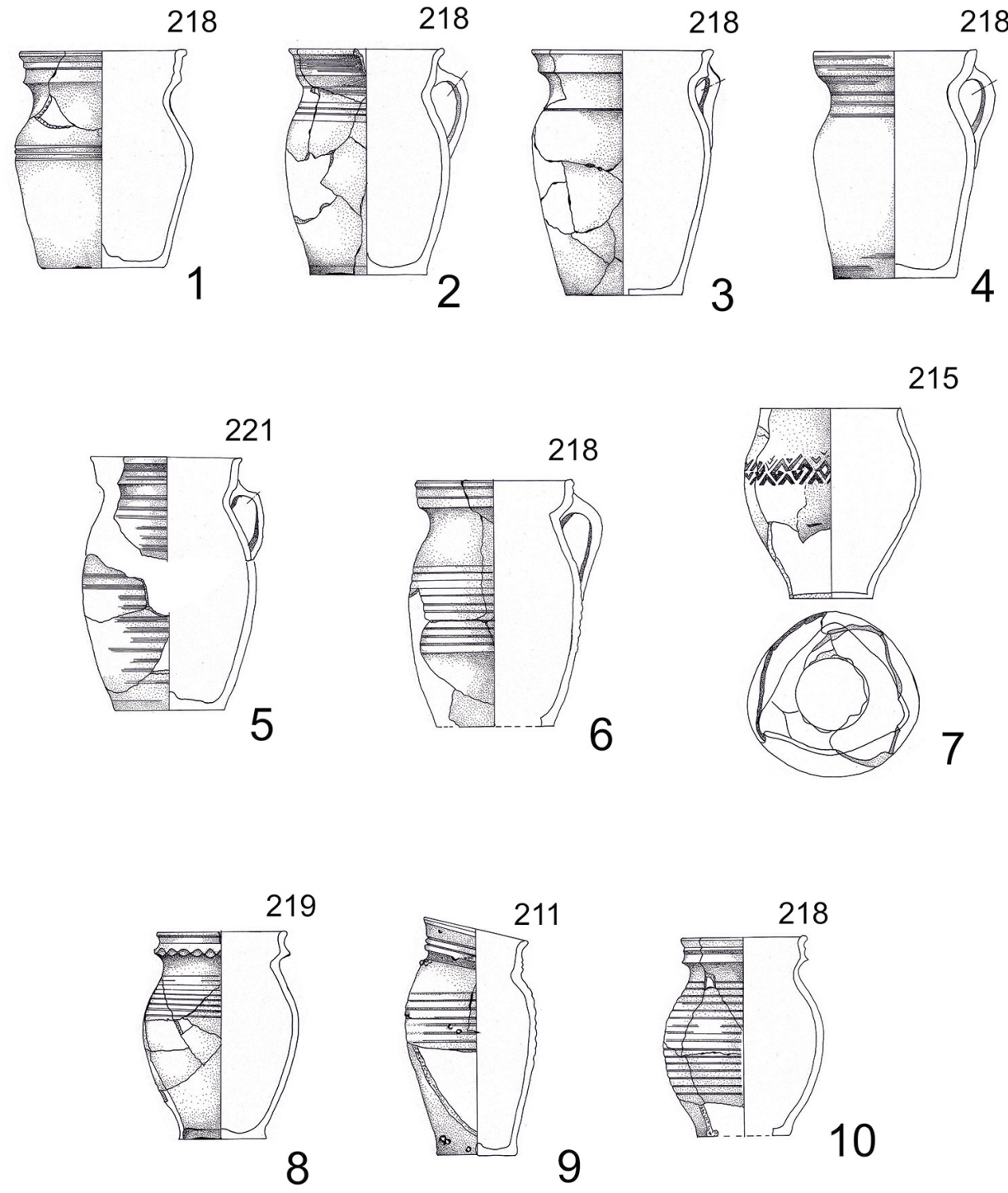

$0 \quad 3 \mathrm{~cm}$

Obr. 10. Výběr keramiky 3./4. horizontu - poháry. 1-6 - tzv. chrudimské poháry; 7 - pohár jihlavského typu s radélkovou výzdobou; 8, 10 - světlé oxidační zboží; 9 - loštický pohár. Trojmístné číslo odpovídá konkrétní keramické technologické třídě. Kresba B. Hlaváčová, P. Jakubková a K. Holínková.

Abb. 10. Keramikauswahl des 3./4. Horizonts - Becher. 1-6 - sog. Chrudimer Becher; 7 - Becher Iglauer Typs mit Rädchenverzierung; 8, 10 - helle Oxidationskeramik; 9 - Loschitzer Becher. Die dreistellige Zahl entspricht jeweils der konkreten technologischen Keramikklasse. Zeichnung B. Hlaváčová, P. Jakubková und K. Holínková. 
glazované zboží typu Husova ulice (Frolík-Sigl 1990; Musil 2009; KT 226, 141 ks, 1935 g), které v souboru zastupují fragmenty kuchyňské (např. obr. 11:1) i stolní keramiky. Toto zboží z Chrudimi bylo distribuováno v rámci celého regionu (Frolík-Kozáková-Musil-Vad’urová 2020, 455; Musil-Netolický-Preusz 2020, Př́loha 1; Lacina-Musil 2020; Musil 2020; Frolík-MácalováStránská 2016, 29-34). Poměrně hojně je zastoupeno jemné režné oxidační zboží (KT 231, 164 ks, 4971 g), které můžeme datovat do průběhu 15. až počátku 16. století. V souboru nalezneme jak kuchyňskou, tak i stolní keramiku (obr. 8:8 a 10:5). Tato jemná keramika je známa jak ze širšího regionu Chrudimska, tak i z prostoru Železných hor (Frolík-Kozáková-Musil-Vad’urová 2020, 455; Musil-Netolický-Preusz 2020, Př́loha 1; Lacina-Musil 2020; Musil 2020; 2014). Obdobně je možno datovat i charakteristickou bíle malovanou keramiku (KT 223, 5 ks, 548 g), která se vyskytuje zejména ve středočeském prostoru, odkud zasahuje do přilehlých regionů. Poprvé se ve středočeském prostoru vyskytuje ve 13. století (Durdík 1983, 211-213). Na Klučově její výskyt spadá do dvacátých až třicátých let 15. století (Kudrnáč 1973, 119), soubor z jeskyně Mincovna u Koněprus do prvních dvou desetiletí druhé poloviny 15. století (Hejna-Radoměrský 1958, 532). Keramika ze zaniklé středověké vsi Oujezd je datována k polovině 15. století, nálezy z Anežského kláštera v Praze (Reichertová 1968) a z Libice nad Cidlinou (Hazlbauer-Špaček 1987, 31) se hlásí do 15. století. Keramický soubor ze zaniklé středověké vsi Vesec a z Čelákovic náleží do poloviny 16. století. Podobně je datována i keramika z Cukmantlu, Litoměřic a Turnova-Sokolova (Hazlbauer-Špaček 1987, 44). Mimo Chrudim (Frolík-Kozáková-Musil 2018) máme tuto keramiku doloženu na hradě Košumberku (Frolík-Musil-Sigl s. d.) či v Kovářově u Seče (Musil-Netolický-Preusz 2020, Př́loha 1).

Svébytné postavení v souboru zaujímají zlomky kachlů, které náleží dvěma keramickým technologickým třídám (KT 222 a KT 236, celkem 125 ks, 5266 g). Kachle komorové a baňkové jsou zastoupeny pouze $\mathrm{v}$ menších zlomcích, kachle nádobkové s pravoúhlým ústím ve větších torzech (obr. 11:6).

Z horních úrovní propadávala i mladší novověká keramika (KT 311-314, 318 a 320, 109 ks, $1543 \mathrm{~g}$ ). Celkem 313 ks, o celkové hmotnosti $6921 \mathrm{~g}$, nebylo možné vzhledem ke špatnému stavu dochování blíže zařadit.

\subsection{Sklo}

Skleněné fragmenty nalezené v odpadní jímce 973 lze rozdělit do dvou základních chronologických horizontů. Nejbohatší soubor skla pochází z prvního horizontu (srov. obr. 3), který je datován do 14. až první poloviny 15. století, a reprezentují jej skla gotického tvarosloví získaná ze spodní části výplně jímky - z rozmezí uloženin $\mathrm{C} 1 / 145$ až C1/123. Charakteristickým sklářským artiklem tohoto období byly různé varianty číší zdobených nálepy, což se projevilo i v charakteru výplně této jímky.

Nejvíce skla gotického tvarosloví obsahovala vrstva $\mathrm{C} 1 / 145$ při dně jímky, která je na základě nálezů grošů Václava IV. datována do přelomu 14. a 15. století (Kozáková-KlikarováFrolík 2010, 137). V této uloženině bylo nalezeno nejméně 20 číší českého typu, ${ }^{2}$ mezi nimiž jsou zastoupeny jak číše vyšší píštalovité, tak i nižší kyjovité varianty. Výraznou variabilitu pozorujeme v provedení jejich dekoru (obr. 14). Vysoké číše s nálepy, označované jako číše českého typu (Heteš 1959), jsou typickým produktem českého středověkého sklářství a od poloviny 14. století se staly dominantním tvarem dutého skla v českých zemích. Jejich velká obliba vedla k tomu, že se rozšiřily i mimo naše země, např́íklad na území Německa, Švédska a Polska. Podle F. Frýdy (1988, 179, 183-185) lze číše českého typu na základě morfologie rozdělit do pěti variant. Pro účely tohoto příspěvku však postačí základní dělení do dvou variant, a to na píštalovité a kyjovité.

Z jímky 973 se podařilo rekonstruovat téměř v úplnosti pouze jednu píštalovitou číši (obr. 12:6), která dosahovala výšky $42,5 \mathrm{~cm}$. Ústí číše o průměru $6,3 \mathrm{~cm}$ je od těla odděleno

2 Minimální počet číši byl stanoven na základě rekonstruovaných patek a jejich torz. 

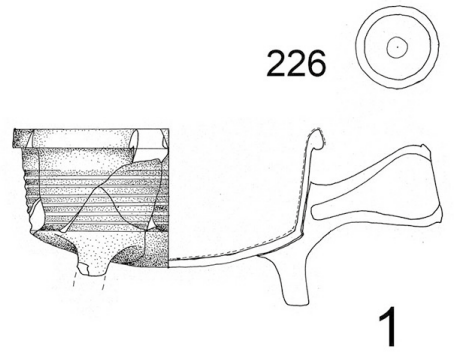

215
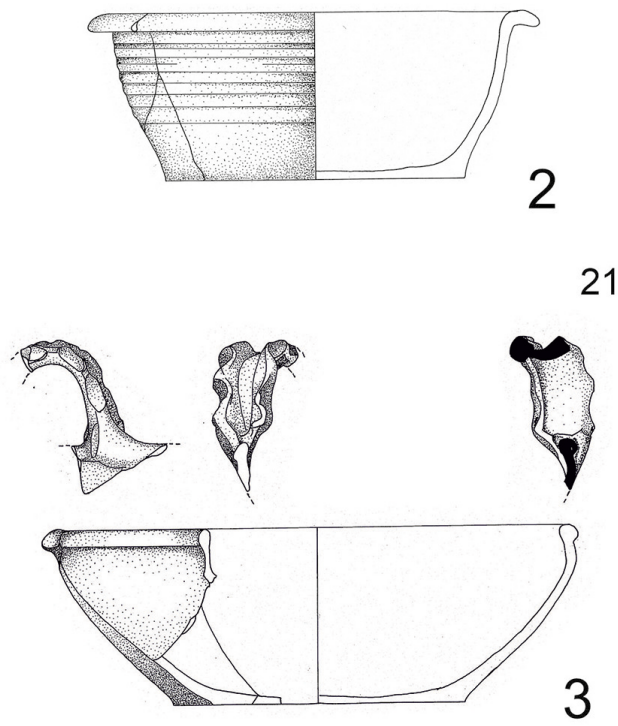

3
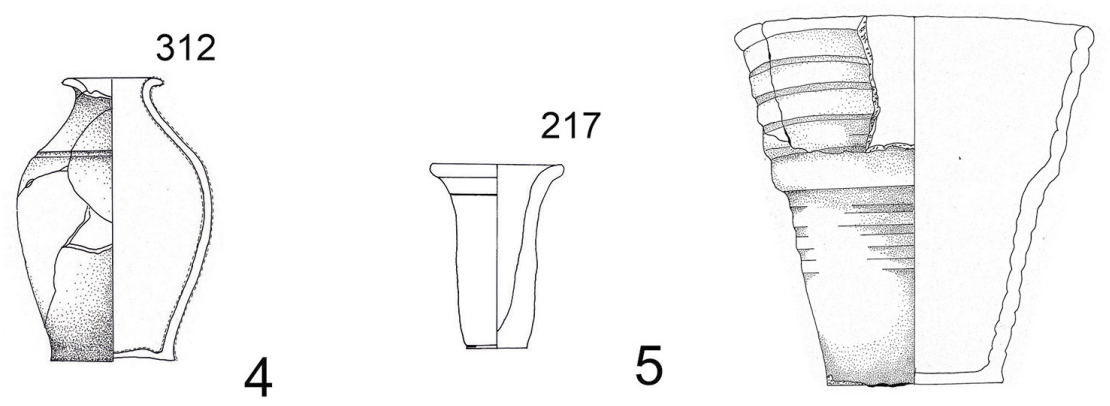

Obr. 11. Výběr keramiky 3./4. horizontu. 1 - trojnožka; 2-3 - mísy; 4 - glazované balsamárium; 5 - tyglíkovitá lampička; 6 - nádobkový kachel s pravoúhlým ústím. Trojmístné číslo odpovídá konkrétní keramické technologické třídě. Kresba B. Hlaváčová, P. Jakubková a K. Holínková.

Abb. 11. Keramikauswahl des 3./4. Horizonts. 1 - Dreifuß; 2-3 - Schüsseln; 4 - glasiertes Balsamarium; 5 - Tiegelartige Lampe; 6 - Topfkachel mit rechteckiger Mündung. Die dreistellige Zahl entspricht jeweils der konkreten technologischen Keramikklasse. Zeichnung B. Hlaváčová, P. Jakubková und K. Holínková. 

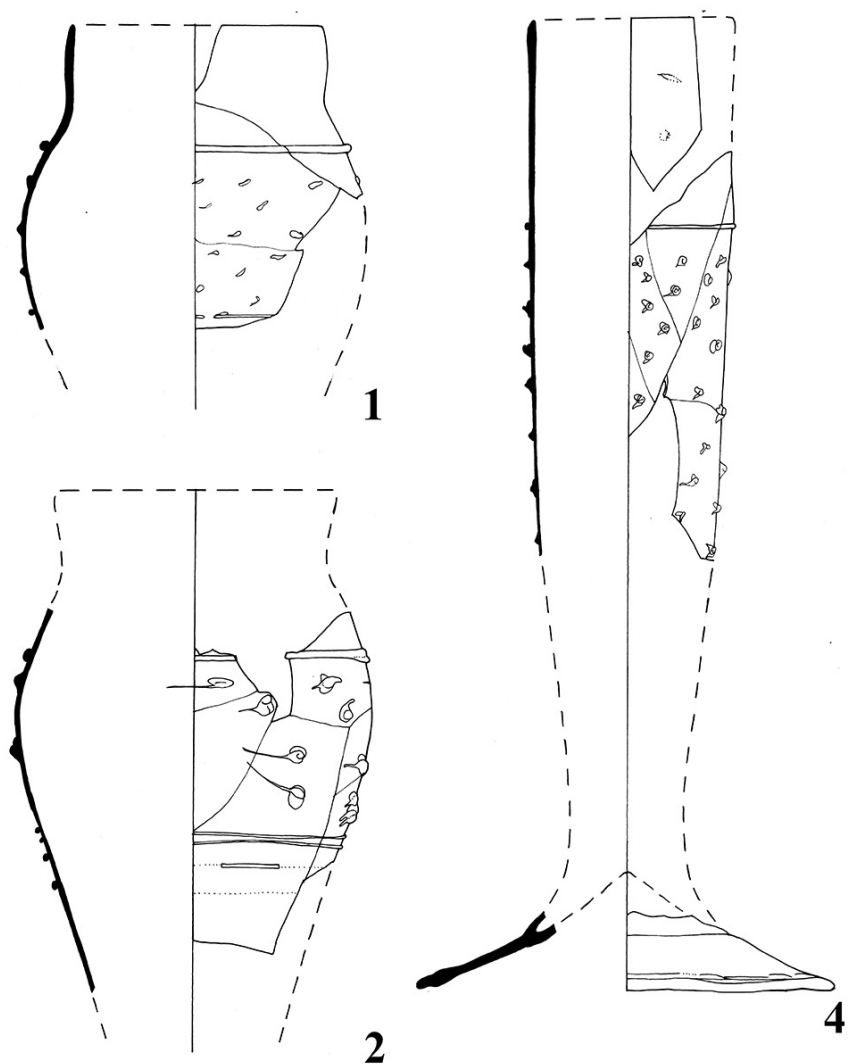

2
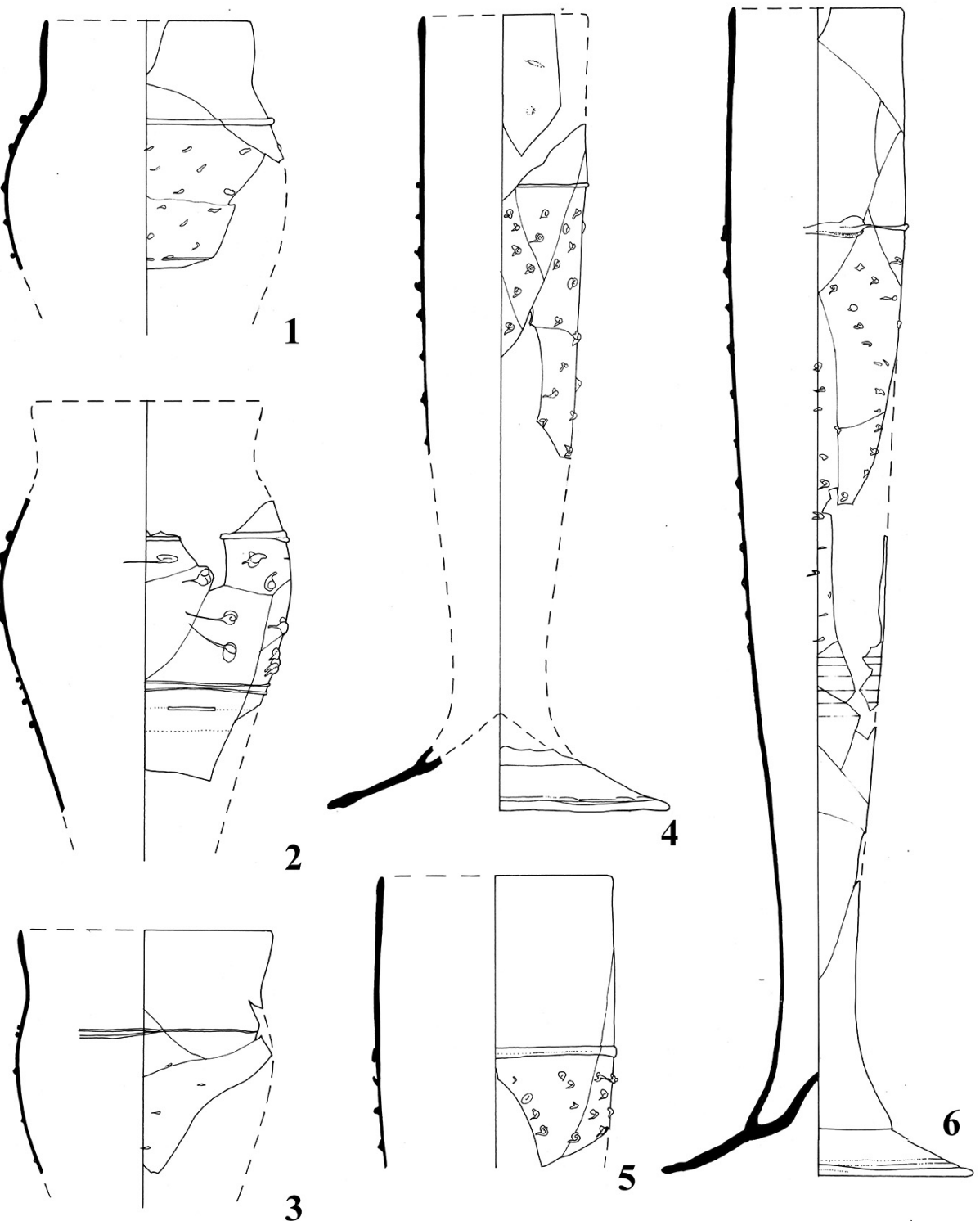

3
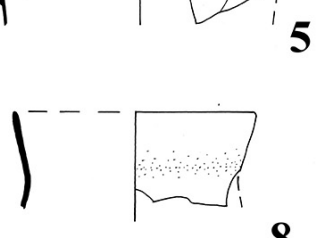

8

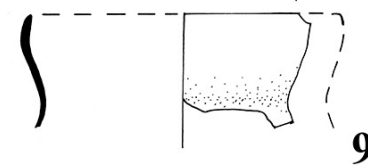

0

Obr. 12. Chrudim, Hradební ulice, jímka 973. Sklo gotického tvarosloví. Kresba K. Vad’urová.

Abb. 12. Chrudim, Hradební-Straße, Grube 973. Glas gotischer Formgebung. Zeichnung K. Vad'urová. 
hladkým vláknem a plynule přechází v tělo, které je zdobené srpečkovými nálepy. Ve spodní části je výzdobný pruh vymezen spirálovitě ovinutým vláknem v šesti řadách nad sebou. Průměr patky této číše, po jejímž obvodu jsou stopy po kleštích, je 11,3 cm. Rekonstruovat téměř celý profil bylo možné i v případě dalších dvou číší, které ale nedosahovaly takové výšky. První z nich, zdobená mírně svinutými až srpečkovými nálepy, byla původně vysoká kolem $30 \mathrm{~cm}$ (obr. 12:4), výška druhé číše se srpečkovými nálepy je odhadována na $35-40 \mathrm{~cm}$. Průměr okraje obou číší je $6 \mathrm{~cm}$ a také patky mají shodný průměr $12,4 \mathrm{~cm}$.

$Z$ dalších číší se zachovaly většinou pouze patky, torza horních částí a zlomky výdutě, které ale již ve většině případů nebylo možné rekonstruovat do původního tvaru. Nejméně dalších deset číší patří $\mathrm{k}$ vyšším píšt’alovitým tvarům s téměř cylindrickým ústím. Z řady těchto číší však svými rozměry vybočují dva exempláře zdobené srpečkovými nálepy, které dosahují v porovnání $\mathrm{s}$ ostatními výrazně větších rozměrů. První z nich, $\mathrm{s}$ okrajem o průměru $10,5 \mathrm{~cm}$, náleží mezi širší varianty píštalovitých číší. Průměr okraje druhé číše je o něco menší, $8,5 \mathrm{~cm}$, přesto svými rozměry předčí ostatní píštalovité číše, jejichž průměr ústí se pohybuje kolem $6-6,5 \mathrm{~cm}$. Nikoliv rozměry, ale provedením výzdoby vyniká číše zdobená diagonálními vlákny promačkávanými rádélkem (obr. 13:2). S tímto typem výzdoby se v Chrudimi setkáváme sporadicky i v jímkách ve Filištínské ulici.

Průměr patek píštalovitých číší z této jímky se pohyboval nejčastěji v rozmezí $12-13 \mathrm{~cm}$ (nejméně 9 jedinců), méně často $11-12 \mathrm{~cm}$ ( 3 jedinci). Další dvě číše nesly patky o průměru kolem $10 \mathrm{~cm}$. U patky o průměru $9 \mathrm{~cm}$ je možné, že pochází z nižší kyjovité varianty. Po obvodu patek jsou často patrné stopy po sklářských kleštích uživaných při tvarování nádob.

Píštalovité číše českého typu mohou dosahovat výšky až $50 \mathrm{~cm}$ a vyznačují se většinou štíhlým vysokým tělem. V českých souborech jsou běžnou součástí výplní středověkých odpadních jímek. Jako př́íklad lze uvést nálezy z Mostu (Černá 1995, 251), Prahy (Žd’árská 2014, 100-104), Kutné Hory (Lehečková 1975, 453-460) a Tábora (Krajíc a kol. 1998, obr. 43). V Chrudimi byly píštalovité číše nalezeny také v dalších jímkách v Hradební a Filištínské ulici, a to jak v provedení se svinutými nálepy, tak s nálepy srpečkovými. Také na Moravě a ve Slezsku patřily mezi běžné vybavení stř̌edověkých měštanských domácností. Č́iše zdobené vlákny promačkávanými rádélkem nejsou tak frekventované jako číše s dekorem v podobě různě provedených nálepů, přesto však patřily k dostupnému zboží v řadě českých a moravských měst. Doloženy jsou např́iklad v Praze (Žd'árská 2014, 102), Plzni (Černá ed. 1994, 88), Chebu (Šebesta 2007, obr. 2), Táboře (Krajíc 1998, obr. 45), Brně (Sedláčková ed. 2019a, 368-370) a Opavě (Sedláčková 2004a, 227, obr. 2: 9).

Druhou variantou číší českého typu jsou nižší číše s výrazně kyjovitým tělem a odsazeným ústím. Č́šse tohoto typu jsou ve vrstvě $\mathrm{C} 1 / 145$ zastoupeny nejméně pěti jedinci, z nichž se zachovala pouze torza či fragmenty. První číše je výrazně kyjovitá a v místě maximální výdutě se nachází výzdobný pás vyplněný svinutými nálepy. Shora je pás vymezen jedenkrát ovinutým hladkým vláknem, zespodu pak nejméně čtyřikrát ovinutým vláknem. Směrem dolů se tělo číše plynule zužuje (obr. 12:2). Podobného tvaru je i druhá číše s užším, téměř cylindrickým ústím, která je však zdobena drobnými srpečkovými nálepy (obr. 12:1). Dekor v podobě srpečkových až čárkovitých nálepů nese také třetí číše, která má ale na rozdíl od předchozího exempláře mírně se rozšiřující nízké ústí (obr. 12:3). Další fragmenty dokládají, že jedna z číší byla ve spodní části pětkrát ovinuta hladkým vláknem (obr. 13:6).

Z těchto kyjovitých číší či z jiného typu číší nebo číšek pocházejí také fragmenty mírně klenutých či mírně rozevřených ústí několika nádob (obr. 12:8,9) a tři patky číší s kónicky se rozevírající spodní částí (obr. 13:8,9). Průměr patek prvních dvou číší je $8,9 \mathrm{~cm}$, třetí patka je o něco menší, 8,3-8,6 cm. V porovnání s píštalovitými variantami číší českého typu měly tedy patky kyjovitých číši značně menší rozměry. Bohužel však ani u jedné z těchto číší nebylo možné rekonstruovat kompletně celý profil. Pokud bylo možné určit zbarvení skla, byly tyto číše vyrobeny z čirého lehce nazelenalého skla.

Kyjovité číše českého typu patři ve středověkých souborech k frekventovaným tvarům. Mezi nejstarší zástupce náleží číše z Kutné Hory datované do poloviny 14. století (Lehečková 1975, 

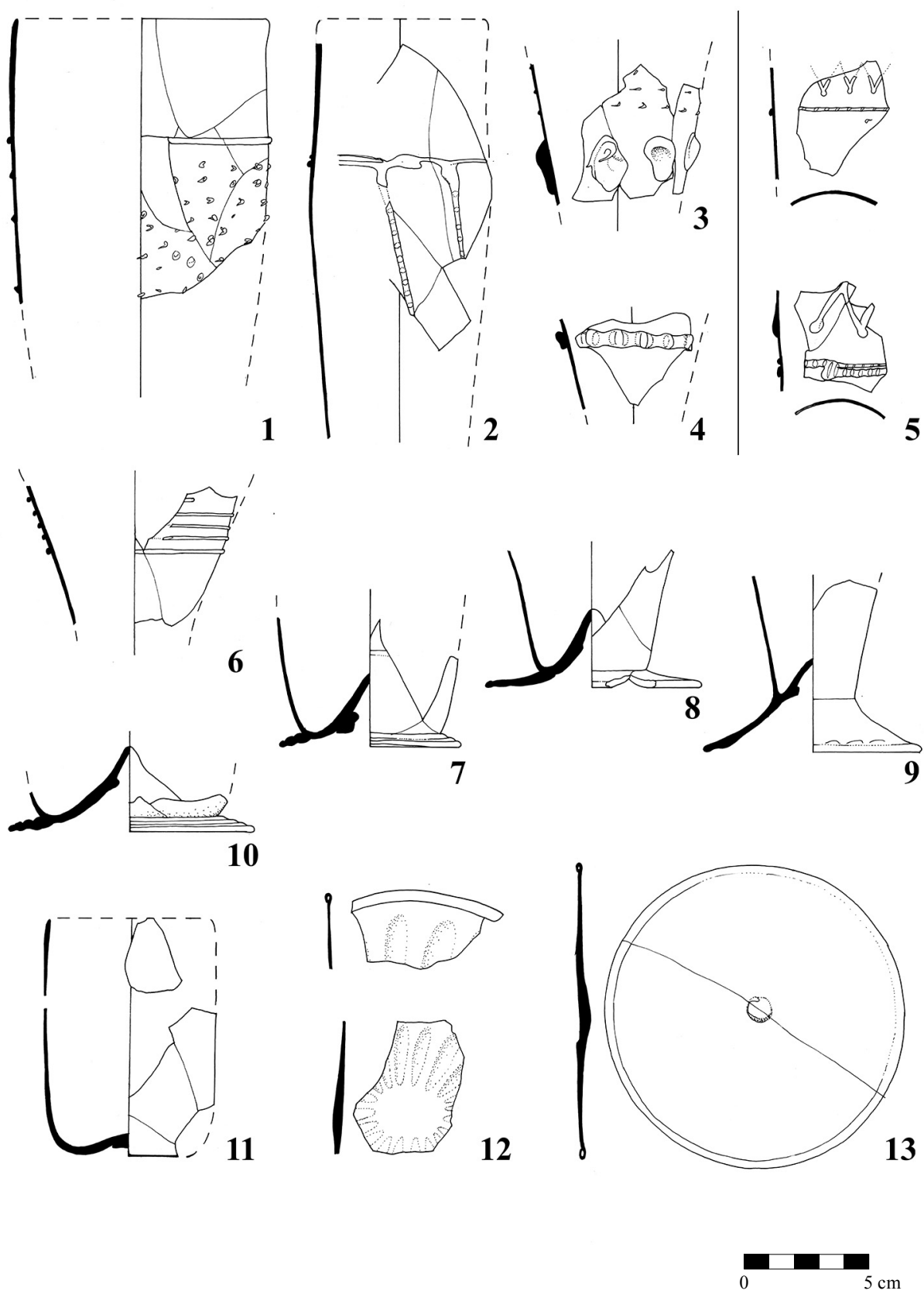

Obr. 13. Chrudim, Hradební ulice, jímka 973. Sklo gotického tvarosloví. Kresba K. Vad’urová.

Abb. 13. Chrudim, Hradební-Straße, Grube 973. Glas gotischer Formgebung. Zeichnung K. Vad'urová. 
456, obr. 8) a ze 14. století z Ústí nad Labem-Hradiště (Černá 1996, obr. 4:1, 5:2, 10:1). Mladší exempláře pocházejí z Prahy (např́iklad Žd’árská 2014, 53, obr. 36:1) a Mostu (Černá 1995, 251). Na Moravě jsou kromě brněnských souborů (Sedláčková ed. 2019a, 370-379) doloženy v Olomouci (Sedláčková 2001, obr. 1:5, obr. 2:9, 11, 12), Jihlavě (Sedláčková 2010, obr. 1) a Opavě (Břečková 2017, obr. 3:7). Běžně používané byly také ve Slezsku, kde jsou znázorněny i na architektonické výzdobě radnice ve Vratislavi (Bizskont 2005, Fot. 9).

Další typ nápojového skla reprezentují číšky se soudkovitým tělem, vpíchnutým dnem a s patkou ze spirálovitě ovinutého hladkého vlákna, z nichž se ve vrstvě 145 zachovaly pouze spodní části dvou exemplářů (obr. 13:7, 10). První z nich má patku o průměru 7,2-7,4 cm tvořenou ze tř́ řad svinutého vlákna, spodní část těla je mírně soudkovitá a ve výšce ca $4 \mathrm{~cm}$ jsou na těle stopy po dvakrát ovinutém vláknu. Druhá číška má patku o průměru $10 \mathrm{~cm}$ vytvořenou ze čtyř řad vlákna. $Z$ některé $\mathrm{z}$ těchto číšek zřejmě pocházejí i fragmenty baňaté výdutě zdobené mírně svinutými nálepy.

Číšky se soudkovitým tělem byly nalezeny i v jiných chrudimských jímkách, např́íklad z jímky 927 bylo získáno několik číšek regionální provenience zdobených nálepy. Podobným soudkovitým tvarem těla se vyznačují i číšky s taženými kapkami, jaké známe z jímky 962 či z jímek ve Filištínské ulici (Frolík-Kozáková-Musil-Vad’urová 2020, 460, 461, obr. 8). Exempláře z jímky 973 však nenesly stopy po dekoru v podobě tažených kapek. Z jímky, z blíže nespecifikované vrstvy, pochází také jednoduchá číška s válcovitým tělem o průměru $6,9 \mathrm{~cm}$ ze zkorodovaného skla (obr. 13:11).

Vedle dutého skla obsahovala vrstva $\mathrm{C} 1 / 145$ i několik fragmentů okenních skel. Okenní sklo je zastoupeno celým okenním terčíkem s přehnutým okrajem (obr. 13:13) a fragmenty terčíku o průměru ca $14 \mathrm{~cm}$ s optickým dekorem koncentrických žeber ze silně zkorodovaného skla (obr. 13:12). Okenní terčíky zdobené optickým dekorem nejsou př́iliš běžné. Několik fragmentů je doloženo v Brně (Sedláčková 2007, Fig. 45), další pocházejí ze severní Moravy - z hradu Cvilín u Krnova (Sedláčková 2004b, 374, obr. 3: 11) a Opavy, kde jsou zastoupeny početněji v kontextech druhé poloviny 15. století (Břečková 2017, 271, obr. 9:3).

Ve vrstvách $\mathrm{C} 1 / 145$ a C1/141 byly nalezeny zcela zkorodované fragmenty skla, z nichž se podařilo rekonstruovat střední část číše s unikátním dekorem. Torzo číše je zdobené drobnými srpečkovými nálepy a pod nimi pásem z velkých plochých protáhlých nálepů (obr. 13:3). V obou zmíněných vrstvách byly nalezeny i fragmenty číše nebo číšky zdobené klikatkou z hladkého vlákna, horizontálními vlákny promačkávanými rádélkem a výrazně zaštípanou páskou (obr. 13:4, 5), ze kterých se ale vzhledem k jejich nevelkým rozměrům nepodařilo rekonstruovat původní tvar nádob. Dekor v podobě natavených klikatek aplikovali stř̌edověcí skláři na různé tvary nádob. Například z Ústí nad Labem-Hradiště pochází láhev s tělem zdobeným horizontální klikatkou (Černá ed. 1994, 29), zatímco z Brna a Olomouce jsou známy číše a číšky s tímto dekorem (Sedláčková 2001, obr. 1:1, obr. 2:5, 9; Sedláčková 2007, Fig. 8). Z Chrudimi byly další fragmenty zdobené natavenou klikatkou získány z jímky 962 (Frolík-Kozáková-Musil-Vad’urová 2020, 460, 461, obr. 8).

Ve vrstvě C1/141 byly dále nalezeny také zlomky výdutí číší českého typu zdobených převážně srpečkovými nálepy (méně nepravidelnými lehce svinutými nálepy). Většina zlomků je silně poškozena korozí, pouze u některých se zachovala původní velmi lehce nazelenalá sklovina. Z řady fragmentů číši se srpečkovými nálepy vybočuje zlomek střední části číše většího průměru, kterou zdobily velmi drobné srpečkové až čárkovité nálepy ohraničené v horní části horizontálním vláknem promačkávaným rádélkem. Na rozdíl od tohoto exempláře je u většiny číší vlákno vymezující zdobenou střední část jednoduché, hladké. Vedle číší zdobených nálepy jsou zde minimálně jedním až dvěma exemplářem zastoupeny píštalovité číše s diagonálními vlákny promačkávanými rádélkem. Bohužel ani jeden exemplář se nepodařilo rekonstruovat v úplnosti.

Mezi vzácné nálezy patří jednoduchý hladký skleněný kroužek o průřezu vlákna ve tvaru „D“ (obr. 12:7), jaké známe již z období raného středověku. Kroužek, o vnějším průměru 1,8 cm, je zcela zkorodovaný, což znemožňuje určení původního zbarvení skla. Skleněné kroužky patřily 
již od 10. století mezi výrobky rozšířené na rozsáhlém území střední, severní a východní Evropy. V českých zemích byly používány především v 11. až 13. století (Černá-Tomková-Hulínský 2015, 81-86; Sedláčková-Zapletalová 2012; Vad’urová 2019). Otázka jejich funkce není spolehlivě vyřešena. Kroužky většího průměru mohly sloužit jako prsteny. U kroužků menšího průměru - podle P. Steppuhna (2002) do 1,4 cm - lze však tuto funkci vyloučit. Je pravděpodobné, že byly využívány jako ozdoby vlasů či oděvu nebo jako korálky do růženců. Vyloučeny nejsou ani další funkce, např́iklad jako nemonetární platidlo (viz Olczak 2007). V Chrudimi byl další kroužek nalezen v jímce A2. Tento kroužek vyrobený z opakního modrého skla má také průřrez vlákna ve tvaru $\mathrm{D}$ a vnější průměr ca 2,5 cm. Pochází však z mladší uloženiny. V Čechách byly analogické exempláře doloženy v hromadném nálezu kroužků v Tleskách (Nechvátal-Radoměrský 1963, 6; Radoměřský 1976). Další jednotlivé nálezy však pocházejí z řady lokalit ze 13. století (Černá ed. 1994, č. kat. 55-58; Černá-Tomková-Hulínský 2015, obr. 3). Několik kroužků podobného průměru vyrobených z různě barevného skla, datovaných do 12. až 14. století, bylo nalezeno v Brně (například Sedláčková-Zapletalová 2012, 543-545) a Konůvkách (Himmelová 1990, 136, č. 33, obr. 2:14).

Další středověké vrstvy byly na sklo o poznání chudší. Z vrstvy C1/139 bylo získáno pouze pět zkorodovaných zlomků těla číše českého typu, z nichž dva jsou zdobeny drobnými perličkovými nálepy. Další dva zlomky s identickou výzdobou byly zachyceny ve vrstvě C1/133. Je pravděpodobné, že tyto zlomky pocházejí z některé z číší, jejichž torza byla získána ze spodních vrstev výplně jímky (vrstvy C1/145 a C1/141).

Nad poslední „gotickou“ vrstvou $\mathrm{C} 1 / 123$ následovalo zhruba $80 \mathrm{~cm}$ mocné souvrství z 15 . až 16. století (vrstvy $\mathrm{C} 1 / 122$ až $\mathrm{C} 1 / 116)$ ), které neobsahovalo žádné skleněné fragmenty. Absence nálezů byla zřejmě způsobena vybíráním jímky jejími někdejšími majiteli.

Druhý horizont skleněných předmětů představují fragmenty z vrstev C1/103-115 a C1/119, které obsahovaly materiál ze 17. století (Kozáková-Klikarová-Frolík 2010, 139). Tyto vrstvy však již obsahovaly sklo renesančního tvarosloví, především fragmenty pohárků s patkou ze svinutého vlákna a množství okenního skla - terčíky i trojúhelníkovité výplně. Z vrstvy $\mathrm{C} 1 / 112$ pochází i střep ze světle modrého skla zdobený tmavě modrou malbou.

Z této jímky byl tedy získán především bohatý soubor skla gotického tvarosloví. Pro určení minimálního počtu nádob lze využít rekonstruovaná torza spodních částí a patek, které se díky svému masivnějšímu provedení zachovaly lépe než tenké fragmenty stěn. Celkem bylo z této jímky získáno nejméně 24 nádob z druhé poloviny 14. až 15 . století, z toho alespoň 21 číší, dvě číšky se soudkovitým tělem a jedna číška s válcovitým tělem. Vzhledem k velké variabilitě dekoru rekonstruovaných číší i neprriřazených fragmentů a početným zlomkům patek, které nebylo možné rekonstruovat, je ale pravděpodobné, že celkový počet nádob byl ještě vyšší (ca kolem 30 kusů).

Za zmínku stojí naprostá absence importovaného skleněného zboží, přestože v chrudimských souborech obecně nejsou importované skleněné nádoby př́liš časté a v ostatních jímkách se objevují pouze v počtu jednotek kusů. Jímka 973 však obsahovala výhradně nádoby domácí české - provenience. Nápojové sklo je zastoupeno převážně číšemi českého typu píštalovité a kyjovité varianty a různého dekoru. Zajímavá je tu absence číší a číšek s taženými kapkami, které byly poměrně hojně zastoupeny ve středověkých vrstvách odpadní jímky 962 v Hradební ulici (Frolík-Kozáková-Musil-Vad’urová 2020, 460, 461, obr. 8), ale také v jímkách ve Filištínské ulici. Č́išky jsou doloženy pouze několika torzy spodních částí, které je ale nedovolují přiřadit konkrétním typům. Tím je sortiment nápojového skla kompletní. V této jímce nebyly nalezeny žádné stolní láhve ani další tvary skla používaného k servírování nápojů. $Z$ nepř́liš početného souboru okenního skla, které reprezentují okenní terčíky s přehnutým okrajem, vybočují fragmenty zdobené optickým dekorem. Tyto nálezy dokládají zasklení oken domu, k němuž jímka náležela, již ve druhé polovině 14 . a první polovině 15 . století.

Srovnáme-li sklo z jímky 973 s již publikovaným souborem z jímky 962 z Hradební ulice, zjistíme, že vedle nápadné absence číšek s taženými kapkami je jímka 973 výrazně chudší, pokud jde o typologické spektrum získaných nádob. Navíc zde nebyly prokázány žádné nádoby zdobené 


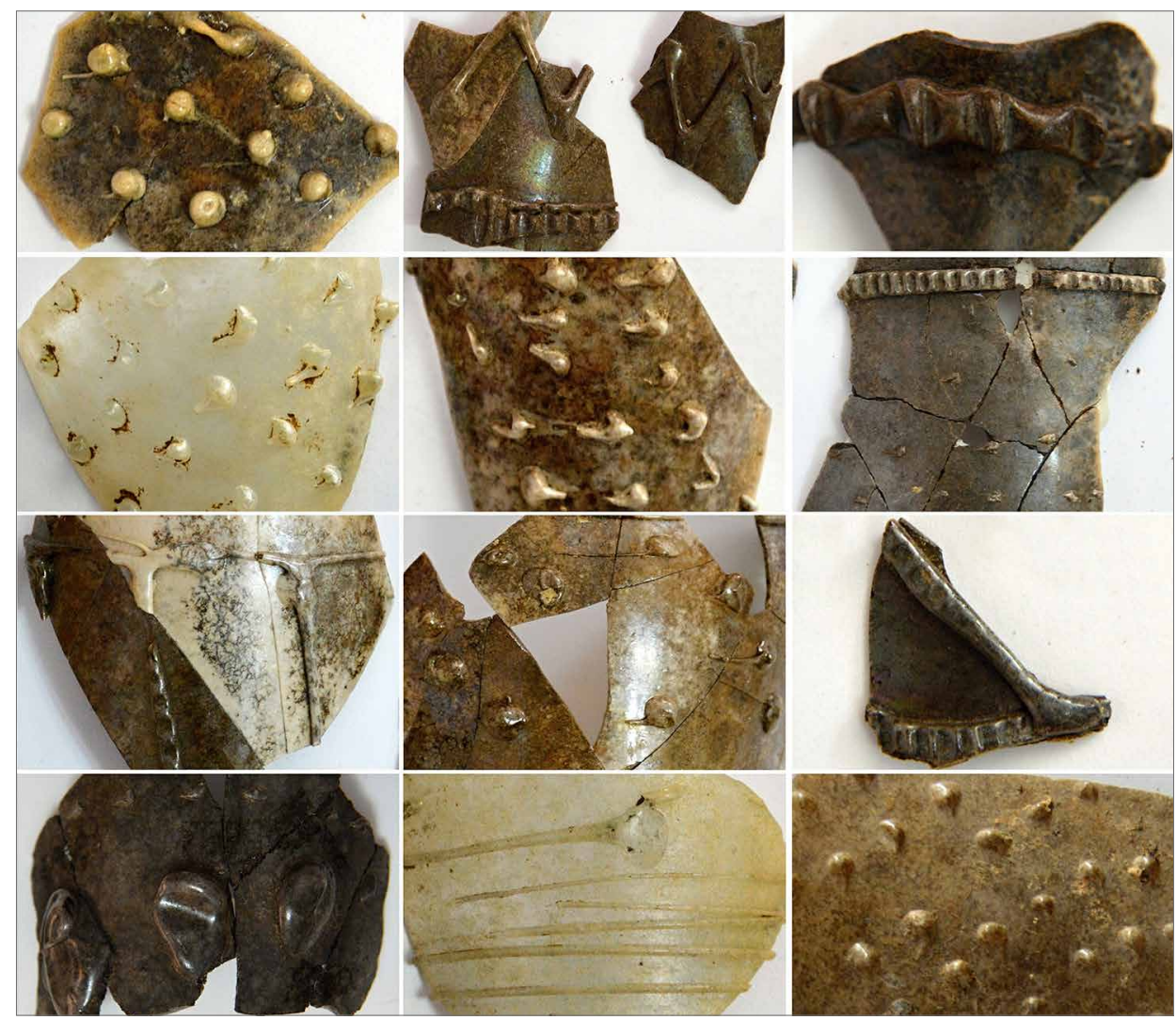

Obr. 14. Chrudim, Hradební ulice, jímka 973. Výběr výzdobných prvků na číších a číškách. Foto K. Vad'urová.

Abb. 14. Chrudim, Hradební-Straße, Grube 973. Auswahl an Zierelementen auf Bechern. Foto K. Vad'urová.

dekorem z tmavě modrého skla, který byl bohatě doložen v jímce 962, ale také v jímce 932 v Hradební ulici. Zda tyto rozdíly poukazují na odlišný ekonomický potenciál či vkus domácností v Hradební ulici, o tom lze dnes již jen spekulovat.

Celkově lze tento soubor interpretovat jako vybavení lépe situované měštanské domácnosti. Přestože zde pozorujeme absenci servírovacích skleněných nádob (stolní láhve, případně konvičky/džbánky), ${ }^{3}$ které se pojí s vysokou kulturou stolování, již samotné užívání nápojového skla v tak časném období a vysoký počet nádob ukazuje spíše na vyšší postavení jeho majitelů. Naprostá dominance skleněných výrobků regionální provenience však dokládá, že jejich uživatelé neměli prostředky či potřebné kontakty k získání luxusního a nákladnějšího skla cizí provenience.

\subsection{Kovy a ostatní materiály}

Jiné materiály než keramika a sklo tvoří jen malou část nálezového fondu. Největší zastoupení má železo (119 předmětů a jejich zlomků). Setkáme se i s předměty z kosti (tři kusy), bronzu (pět kusů), olova (jeden předmět) a kamene (jeden předmět). Specifickou kategorii tvoří mince ( 25 ks).

3 Obecně se však servírovací skleněné nádoby v tomto období objevují pouze sporadicky, a to především v prostředi nejvyšších společenských vrstev. 
Mezi železnými předměty zde, stejně jako v jiných archeologických situacích převažují hřebíky nebo jejich zlomky $(97 \mathrm{ks}, 637 \mathrm{~g})$. Jejich rozložení v jímce není rovnoměrné a zčásti odpovídá předpokládanému původu jednotlivých uloženin. Ve spodní části jímky (uloženiny $\mathrm{C} 1 / 145$ až $\mathrm{C} 1 / 123)$ je to 20 kusů (105 g) s velkým podílem neurčitelných, protože značně zkorodovaných kusů. Střední část výplně (uloženiny C/125 až C1/114) poskytla 19 kusů (130 g). V nejmladší části výplně (uloženiny $\mathrm{C1} / 112$ až C1/103) bylo objeveno 58 kusů (402 g). Velký podíl nalezených hřebíků (klasifikovány byly podle typologie R. Krajíce 2003, 61-69) můžeme spojit s užitím ve stavebních konstrukcích $(25 \mathrm{ks})$ zejména v mladších dvou vyčleněných horizontech, které mají uloženiny charakteru stavební destrukce nebo planýrek (21 ks, typy IIIA, IIIB, VIIIA, VIIIB). Se stavebními konstrukcemi mohou souviset i další typy (IA, IC, IIA, IIB), podle analogií se spojovacím či upevňovacím využitím (11 ks), soustředěné v nejmladším horizontu. Objevují se i hřebíky šindeláky (typ VC, 6 ks). Zajímavý je výskyt hřebíků podkováků ( 7 ks, typy IV a VA). V jiných nálezech totiž, s jedinou výjimkou, nebyly objeveny stopy po užívání koně na parcele (viz níže). Hřebíky uvedených typů však mohly být použity i k jinému účelu (upevnění obruče apod.). Mezi dalšími předměty identifikujeme v nejstarším horizontu jen torzo železného pásku, snad část stavebního kování. Čtyři předměty byly vyzdviženy ze středního horizontu. Zužující se ploché kování (obr. 15:8) je chronologicky necitlivé. Ze stejné uloženiny $(\mathrm{C} 1 / 115)$ pochází také železný kroužek, eventuálně jednoduchá kruhová přezka (obr. 15:10), která je obvyklým nálezem, jenž spadá do celého průběhu vrcholného stř̌edověku (Frolík 2019; Mazáčová 2012; Šlancarová 2018; Unger 2011; Zůbek 2002), a to $\mathrm{v}$ provedení ze železa nebo bronzu. Stejný předmět bychom nalezli také mezi součástmi koňského postroje. V uloženině $\mathrm{C} 1 / 117$ byl objeven silně zkorodovaný zlomek, který je zřejmě částí ostruhy s kolečkem (obr. 15:11). Kolečko samo je překryto korozními produkty, a proto je bližší klasifikace problematická. Obecně jde o předmět, který se objevuje ve 14. až 15. století. Je také možnou indicií využívání (a tudíž ustájení?) koně na parcele. S vybavením domácnosti souvisí dva zlomky otočného klíče s kruhovým okem a dutým dříkem. Tvar brady nelze spolehlivě určit (obr. 15:12). Jedná se o běžný typ, doložený ve 14. až 15. století (Krajíc 2003, 91-94). V nejmladším horizontu se objevuje zlomek nože (obr. 15:9) a zlomek plechu, který snad tvořil obložení jinak neurčitelného předmětu.

Nálezy z barevných kovů jsou vytvořeny z bronzu a olova. Nejvýznamnějším bronzovým předmětem je masivní schránka na ampule se svěcenými oleji - tzv. chrismatorium, která byla vyzdvižena z uloženiny $\mathrm{C} 1 / 145$ (obr. 16). Na vnitřní straně víčka nalezneme rytá písmena $\mathrm{C}$, I, $\mathrm{S}$, která označovala jednotlivé druhy svěcených olejů. Detailnímu rozboru tohoto významného artefaktu je věnována samostatná studie (Bláha a kol. v tisku). Tento církevní předmět pocházející ze 14. století byl druhotně provrtán a užit jako schránka na mince.

Dalším předmětem je zlomek přezky z uloženiny $\mathrm{C} / 112$ (obr. 15:4), tedy z nejmladšího horizontu. Dochovala se rohová část snad obdélného rámečku s ven vytaženým okrajem. Celkové provedení je nejasné. Dochovaná část profilace přes svou neúplnost odpovídá mladšímu chronologickému zařazení (16.-17. století). Je pravděpodobné, že se jedná o přezku z boty, v tom prrípadě by byla nejspíše dvojdílná. Zbývající bronzové předměty jsou zastoupeny amorfními hrudkami (z nejmladší - uloženina C1/103 - a nejstarší - uloženina C1/145 - části výplně). Z olova bylo vyrobeno mírně nepravidelné nevelké kolečko se středovým otvorem (obr. 15:6) pocházející z uloženiny $\mathrm{C1} / 109$ (5 g). Jedná se o předmět nejasného užití, který se v poslední době stále častěji objevuje v archeologických situacích (Bláha a kol. 2011; Pták a kol. 2018). Chronologicky zařaditelné exempláře náleží převážně do mladohradištního období, předmět je tedy ve výplni jímky druhotnou starší příměsí. Analogické, převážně nestratifikované, nálezy známe také z Chrudimska, publikovány byly jenom zčásti (Frolík 2019, 201, 204). Přiřadit sem můžeme také rukojet' železného nože $s$ dochovaným dřevěným obložením, upevněným ke střence sedmi drobnými (bronzovými?) nýtky. Na konci rukojeti je dalších pět uspořádáno do kř́žze. Rukojet' (obr. 15:1) pochází z nejstaršího horizontu (uloženina C1/144). Jedná se o část stolní výbavy. Podobné střenky (provedené z kosti) známe také z dalších jímek (Frolík-Kozáková-Musil 2018, 477, 479). 


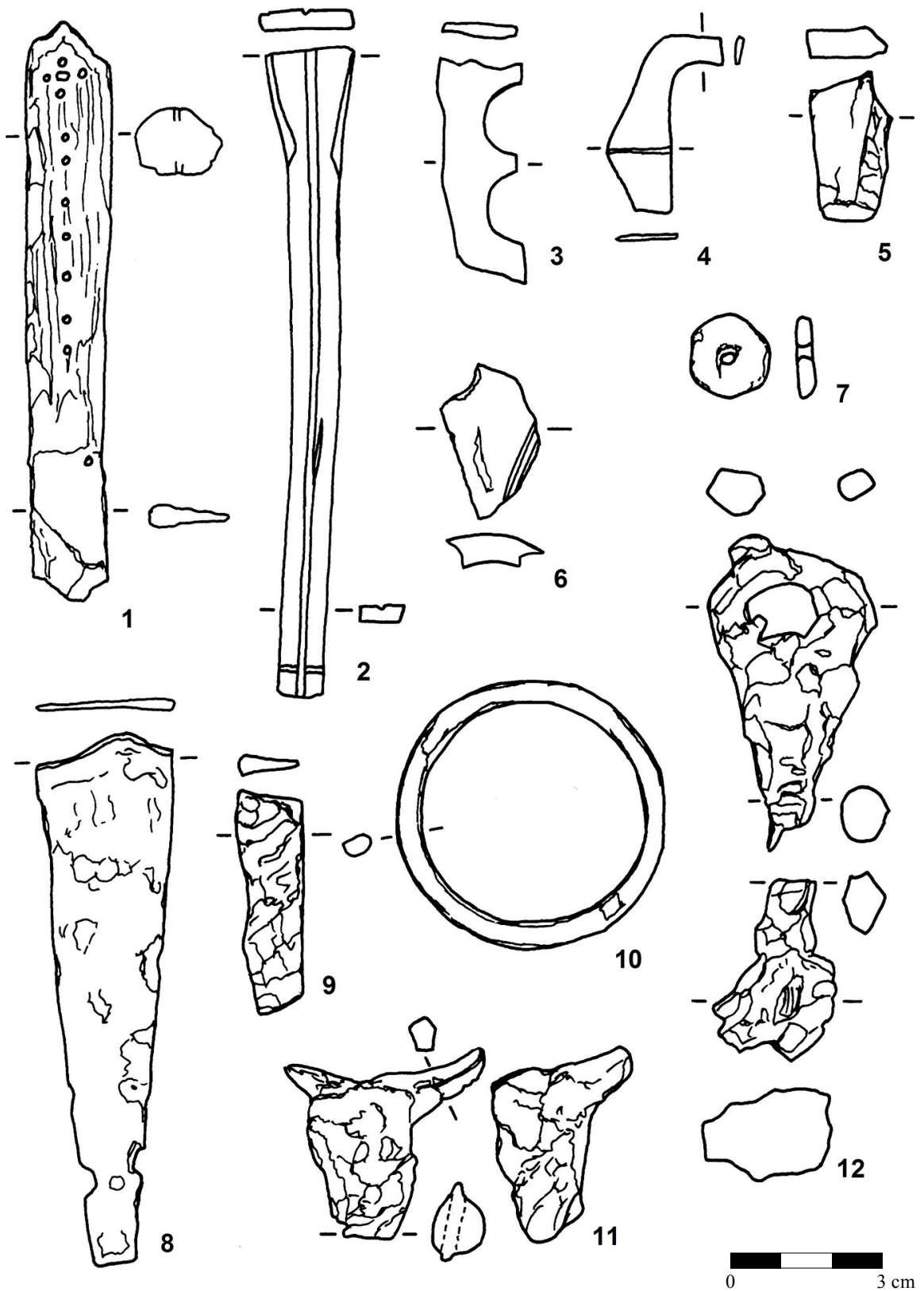

Obr. 15. Chrudim, Hradební ulice, jímka 973. 1 - rukojet' nože s dřevěným obložením; 2 - kostěné obložení; 3 - odpad z výroby knoflíkủ nebo korálků; 4 - část přezky; 5 - křesací kámen; 6 - kost se zářezy; 7 - kolečko se stř̌edovým otvorem; 8 -ploché kování; 9 - nůž; 10 - kroužek/přezka; 11 - ostruha; 12 - otočný klíč. 1 - železo a dřevo; 2, 3, 6 - kost; 4 - bronz; 5 - kámen; 7 - olovo; 8-12-železo. Kresba J. Frolík.

Abb. 15. Chrudim, Hradební-Straße, Grube 973. 1 - Messergriff mit Holzummantelung; 2 - Beinummantelung; 3 - Abfall aus der Knopf- oder Perlenherstellung; 4 - Teil einer Schnalle; 5 - Feuerstein; 6 - Knochen mit Einkerbungen; 7 - Rädchen mit Mittelloch; 8 - flacher Beschlag; 9 - Messer; 10 - Ring/Schnalle; 11 - Sporn; 12 - Drehschlüssel. 1 - Eisen und Holz; 2, 3 , 6 - Bein; 4 - Bronze; 5 - Stein; 7 - Blei; 8-12 - Eisen. Zeichnung J. Frolík. 
Ke kovovým nálezům, tentokrát $\mathrm{z}$ drahého kovu, řadíme ještě mince. $\mathrm{V}$ uloženině C1/141 bylo objeveno minimálně 17 mincí velikosti pražského groše silně napadených korozí. Určení některých z nich dovolily pouze otisky jinak zaniklých líců v korozních produktech. Ty mince určily jako groše Václava IV. (1378-1419). Dalších šest zcela zkorodovaných mincí (groše stejného panovníka?) pochází z uloženiny $\mathrm{Cl} / 145$. V uloženině $\mathrm{C} 1 / 123$ byla objevena prokorodovaná mince také velikosti groše. Ve spodní části jímky byl tedy rozptýlen soubor minimálně 24 grošů (minimálně zčásti Václava IV.). Do jímky se musel dostat náhodně nebo jako důsledek neštastné události. $\mathrm{S}$ ohledem na nález schránky s přihrádkami (chrismatoria) o velikosti pražského groše je pravděpodobné, že mince byly uloženy právě v ní. Při pádu předmětu do nezkonsolidovaného obsahu jímky se vysypaly a rozptýlily do několika uloženin. Charakter výplně víceméně vylučoval úspěšný pokus o jejich vyzdvižení. Jiná, neurčená drobná mince byla nalezena v uloženině $\mathrm{C} 1 / 137$.

Kostěné předměty jsou zastoupeny zlomkem odpadu z výroby kroužků (knoflíků, korálků obr. 15:3) z uloženiny $\mathrm{C} 1 / 115$. Časově zařadit ho můžeme jen na základě výskytu v nejmladším horizontu. Jiný doklad práce s kostí může představovat malý zlomek se dvěma rovnoběžnými rýhami (obr. 15:5) ze středního horizontu (uloženina C1/121). Za nesporný doklad práce s kostí na parcele domu čp. 10/I je nepovažujeme. Pocházejí z rozdílných časových horizontů a je jich málo. Z nejstarší uloženiny $\mathrm{C1} / 145$ byl vyzdvižen úplně dochovaný díl kostěného obložení (obr. 15:2). Jedná se o úzký obdélný předmět, který se na jednom konci nálevkovitě rozšiřuje. Stř̌edem předmětu probíhá mělký žlábek. Může se jednat o obložení nějaké skř́ínky nebo podobného předmětu, jednoznačné určení není možné. Kamenným artefaktem je křesací kámen z pazourku (obr. 15:5) z nejmladšího horizontu (uloženina $\mathrm{C} 1 / 104)$. Nálezy z dalších jímek (Frolík-Kozáková-Musil 2018, 479-480) dokládají, že se jednalo o běžný předmět.

Vyhodnoceny byly také nálezy zlomků mazanice (Netolický 2009, 2010). Z jímky 973 bylo zpracováno celkem 112 zlomků, ale jejich vypovídací hodnota je omezená. Jeden zlomek nese otisk tesaného prvku širokého $3,5 \mathrm{~cm}$. Na dvou se dochovaly negativy jednoho prutu. Další čtyři mají hlazenou úpravu vnější strany, jiných deset má jemně hlazenou vnější stranu s bělošedým nátěrem (Netolický 2009, 30). Zástavba na parcele domu čp. 10/I zjevně kombinovala konstrukce zděné (zlomky malty v uloženině $\mathrm{C1} / 137$ ) a dřevohlinité. U těch nelze pro fragmentárnost určit, zda byly roubené, drážkové nebo hrázděné. Všechny lze na v Hradební ulici doložit na sousedních zkoumaných parcelách čp. 14/I a 15/I (Netolický 2010).

\subsection{Osteologické a parazitologické nálezy}

Prostředí parcely domu čp. 10/I dokreslují osteologické nálezy a také rozbor parazitů z jímky. Osteologické nálezy byly hodnoceny v rámci tří předběžně časově určených horizontů (Baloghová 2010), které odpovídají třem částem zvrstvení popsaným výše a reflektují jejich rozdílný charakter. Celkem bylo z jímky vyzdviženo 1804 kostí nebo jejich zlomků. Neurčeno zůstalo 253 zlomků. Nejvíce kostí bylo analyzováno ze spodní části jímky (uloženiny v rozmezí C1/145 až C1/123), a to 1183 kusů. Převažují savci $(68,5 \%)$, následují kosti ptáků $(13,9 \%)$ a ryb $(0,7$ \%). Nejvíce zastoupeným savcem je prase domácí (minimálně 9 jedinců), následuje tur a ovce nebo koza. Zajímavé je hojné zastoupení kočky domácí (70 kostí, nejméně 4 jedinci starší 6 měsíců) a psa (6 kostí, 1 jedinec) se značnou kohoutkovou výškou $(75 \mathrm{~cm})$. Minimálně je zastoupena lovná zvěř (zajíc -4 kosti a veverka - 1 kost). Prostředí parcely dokresluje kost myši. Mezi ptáky převažuje kur domácí ( 87 kostí), ojediněle se objeví husa (2 kosti), obecně hrabaví jsou zastoupeni 72 kostmi. Střední horizont (v rozsahu uloženin C1/122 až C1/116) obsahuje mnohem menší množství zvířecích kostí (193 kusů). Mezi savci převažuje tur domácí (21 kusů) nad prasetem (10 kostí). Objevuje se také ovce/koza, pes (1 jedinec), kočka (1 jedinec). Lovnou zvěř zastupuje ojedinělá kost zajíce. Méně než v předchozím horizontu jsou zastoupeni ptáci - kur domácí (3 kosti), husa (1 kost). Ještě méně kostí obsahoval nejmladší horizont (uloženiny C1/115 až C1/103) - 175 kusů. Opět převažuje tur domácí ( 25 kusů) nad prasetem (7 kusů) a ovcí či kozou (6 kusů). Objevila 
se také kost koně (1 kus). Opakuje se přítomnost kočky (1 kost) a zajíce (1 kost). Minimálně se objevují ptáci (kur domácí 2 kosti, kachna 1 kost, pěvec velikosti špačka 1 kost - všechny početní údaje podle Baloghová 2010).

Můžeme shrnout, že v nálezech jednoznačně dominují domácí zvířata. S lovnou zvěří se setkáváme jen ojediněle. Kosti nesou charakteristické stopy po dělení a kuchyňském opracování. I přes větší počet kostí tura na počet zjištěných jedinců dominuje prase domácí ve věkovém složení 2-7 týdnů (2 jedinci), 4-6 měsíců (5 jedinců) a 14-16 měsíců ( 2 jedinci) v nejstarším horizontu, ale obdobné složení najdeme i v obou mladších horizontech. Věk mezi 4-6 měsíci by odpovídal porážce na maso, ale doklady chovu z parcely neznáme. Je proto pravděpodobné, že maso bylo kupováno u řezníka. Novorozená selata byla považována za lahůdku, což může souviset s výskytem nejmladších jedinců (Baloghová 2010, 33). Druhým nejčastěji konzumovaným masem bylo kuřecí. Kur domácí je zastoupen převážně kostmi končetin. Přítomnost kosti veverky hodnotíme jako náhodnou. Malé je zastoupení jiné lovné zvěře (jen zajíc). Nabízela by se souvislost mezi větším druhem psa a lovem, ale pro toto tvrzení schází doklady. Nepřímo přítomnost psa ještě dokládá okousání kostí (nejmladší horizont - Baloghová 2010, 32-34). Nevelký výskyt kostí ryb je spojován s malým počtem vyplavených vzorků.

Obsah jímky byl vyhodnocen také z hlediska paleoparazitologie (Bartošová 2009), konkrétně ve dvou vzorcích, $v$ nichž byla detekována přítomnost tenkohlavce lidského (Trichurus trichiura), která se projevuje úpornými průjmy. Ukazuje na špatné hygienické podmínky na dvoře (Bartošová a kol. 2011). V jímkách na sousedních parcelách bylo zastoupení parazitů druhově i množstvím mnohem větší.

\section{Závěr}

Parcela domu č. p. 10/I v Rybičkově ulici v Chrudimi je prŕíkladem situace, kdy se pokoušíme rekonstruovat vývoj a každodenní život na základě svědectví jediné, byt' nálezově poměrně bohaté odpadní jímky. Nemovitost byla, pravděpodobně po značném poškození, obnovena až po roce 1705. Pro starší období schází jakékoliv písemné prameny. Až do třicetileté války byla parcela prostorově stísněná, za domem se nacházel jen nevelký dvorek, nedovolující hloubení většího počtu jímek (jedna byla detailně zkoumána, druhá je doložena díky terénním pozorováním). Na základě stratigrafie byla jímka rozdělena na tři vývojové horizonty, podle keramiky také na tři (ale nikoliv ze stejných uloženin), podle skla pouze na dva horizonty. Obdobnou situaci známe i z dalších jímek z Hradební ulice (jímky 938 a 962 - Frolík-Kozáková-Musil 2018; Frolík-Kozáková-Musil-Bad'urová 2020). Výplň jímky vykazuje ve spodních partiích stopy částečného vybírání výplně, ve skle i keramice chybí jednoznačné nálezy 16. století. Obdobný je vývoj po konci užívání jímky. Sesedání výplně nutilo majitele parcely zasypávat vznikající proláklinu. To se v jímce 973 stalo až v období obnovy nemovitosti po třicetileté válce a tato dodatečná výplň vytvořila asi třetinu objemu.

Nálezy z období využívání jímky (14.-15. století) dokládají, že zástavba na parcele kombinovala zděné a dřevohlinité konstrukce. Je pravděpodobné, že nejméně jednou vyhořela, ale byla obnovena. Nejméně od 15 . století byl dům vybaven okny se skleněnými terčíky. V stejném období se objevují také kachlová kamna, včetně méně obvyklých kachlů baňkových. Typové zastoupení dokládá, že zlomky kachlů pocházejí z více kamnových těles. Jímka vyřazená z užívání (a nahrazená jinou, nezkoumanou?) byla překryta valounovou dlažbou a na jejím místě zřejmě stála stavba na podezdívce využívající starší gotický architektonický článek. Jiná lehká stavba byla na stejném místě postavena až po zaplnění prosedliny a po obnově domu v 18. století.

Nálezy nedovolují úvahy o řemesle nebo podobných aktivitách neznámých držitelů nemovitosti. Málo obvyklá je doložená konzumace novorozených selat, minimálně se objevuje lovná zvěr. Zajímavé je početné zastoupení koček a psa o velké kohoutkové výšce (loveckého?). Neutěšenou hygienickou situaci naznačují nálezy parazitů. 

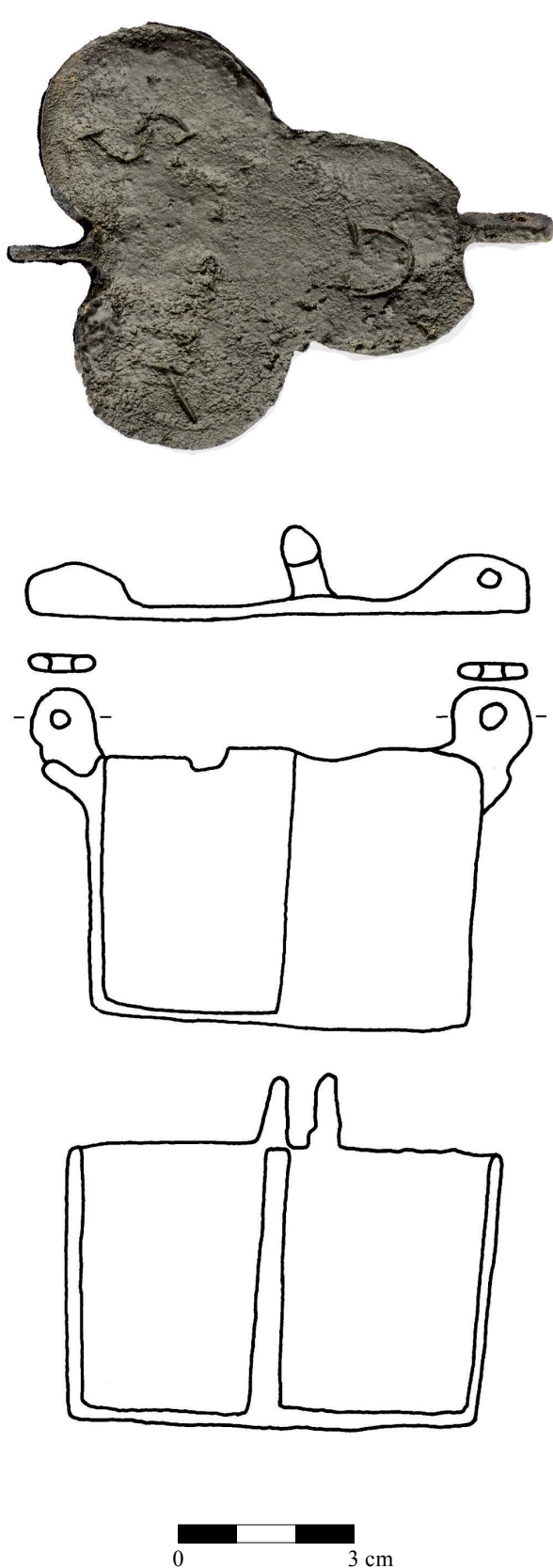

Obr. 16. Chrudim, Hradební ulice, jímka 973. Chrismatorium - nádobka na ampule se svěcenými oleji, druhotně upravená na pokladničku. Foto J. Musil, kresba J. Frolík.

Abb. 16. Chrudim, Hradební-Straße, Grube 973. Chrismatorium - Gefäß für Ampullen mit Salbölen, sekundär zu einer Geldschatulle umgearbeitet. Foto J. Musil, Zeichnung J. Frolík.
Bohaté keramické nálezy (minimálně 446 nádob) ukazují na hojné užívání běžné domácí keramiky z Chrudimi, ale také z Čáslavi, Ledče nad Sázavou nebo Chotěboře. Patrný je př́sun domácí luxusnější keramiky (Loštice, Jihlava, střední Čechy). Zahraniční je doložena jen jednotlivostmi. Podobné je to i v případě skla, které také pocházelo $\mathrm{z}$ domácího prostředí. Zdá se tedy, že přes možnost získat domácí produkty $\mathrm{v}$ hojném množství byly přímé či nepřímé kontakty se zahraničím velice omezené. Pozoruhodný je soubor 24 grošů Václava IV., který byl patrně uložen $\mathrm{v}$ druhotně upraveném chrismatoriu (schránce na ampule se svěceným olejem). Nabízelo by se získání předmětu v souvislosti s husitskými událostmi (v Chrudimi v roce 1421) a následná pro majitele neštastná ztráta.

Rozbor obsahu jedné jímky dovolil alespoň rámcově rekonstruovat podobu jedné vrcholně středověké domácnosti, která je jinak zcela anonymní. Lze předpokládat, že analýza dalších jímek dovolí získat podobný obraz také pro další parcely, a to nejen v Hradební ulici.

Tato práce byla podpořena Grantovou agenturou České republiky, číslo GA 19-05677S „Sklo v českých zemích od gotiky do baroka podle nálezů v Chrudimi a Brně. Význam regionální produkce v evropském kontextu“.

\section{Prameny a literatura}

BALOGHOVÁ, R., 2010: Archeozoologie tři vrcholně středověkých městských parcel v Chrudimi - Hradební ulici. Nepublikovaná diplomová práce, Př́rodovědecká fakulta, Jihočeská univerzita v Českých Budějovicích.

BARTOŠOVÁ, L., 2009: Paleoparazitologická analýza organických sedimentů archeologického naleziště v Chrudimi. Nepublikovaná diplomová práce, Př́rodovědecká fakulta, Jihočeská univerzita v Českých Budějovicích.

BARTOŠOVÁ, L. a kol., 2011: Bartošová, L.-Dittrich, O.-Beneš, J.-Frolík, J.-Musil, J., Paleoparasitological Findings in Medieval and Early Modern Archaeological Deposits from Hradební Street, Chrudim, Czech Republic, IANSA 11, č. 1, 39-50. 
BĚLINOVÁ, K. D.-MUSIL, J., 2011: Tyglíkovité lampičky z Chrudimi, Chrudimský vlastivědný sborník $15,39-59$.

BIZSKONT, J., 2005: Późnośredniowieczne szklarstwo na Śląsku. In: Wratislava Antiqua 7. Wrocław.

BLÁHA, R.-FROLÍK, J.-SIGL, J., 2003: Nálezy loštické keramiky ve východních Čechách. Příspěvek ke kontaktům východních Čech a severní Moravy - Funde der Losticer Keramik in Ostböhmen. Beitrag zu den Kontakten Ostböhmens und Nordmährens, AH 28, 525-537.

BLÁHA, R. a kol., 2011: Bláha, R.-Hejhal, P.-Skala, J., Raně středověké olověné artefakty z katastru Roudnice (okr. Hradec Králové). In: P. Argenti fossores et alii. Znaczenie gospodarcze wschodnich części Górnego Śląska i zachodnich krańców Malopolski w późnej fazie wczesnego średniowiecza (X-XII wiek) (Boroń, P., ed.), 289-305. Wroclaw.

BLÁHA, R. a kol., v tisku: Bláha, R.-Frolík, J.-Musil, J.-Sehnoutková, P., Schránka na svaté oleje z Chrudimi, Hradební ulice, AVČ.

BŘEČKOVÁ, K., 2017: Středověké sklo z Opavy II. Nálezy skla z archeologických výzkumů na ulici Masařská 6, Pekařská - Kolářská a Mnišská - Mezi Trhy, PA CVIII, 257-289.

CEJPOVÁ, M., 2008: Zbyslavec, okr. Chrudim, Výzkumy v Čechách 2005, 312.

ČAPEK, L., 2020: Studium keramiky vrcholného a pozdního středověku v Čechách - témata, metody, př́istupy - Zum Studium der Keramik des Hoch- und Spätmittelalters in Böhmen - Themen, Methoden, Vorgehensweisen, AH 45, 855-887. https://doi.org/10.5817/AH2020-2-16

ČERNÁ, E., 1995: Nálezy skel ze středověkého Mostu - Mittelalterliche Gläser aus Most. In: Archeologické výzkumy v severozápadních Čechách v letech 1983-1992 (Blažek, J.-Meduna, P., edd.), 239-262. Most.

- 1996: Středověké sklo z Ústí n. L. - Hradiště. Ústecké muzejní sešity. Ústí nad Labem.

ČERNÁ, E.-TOMKOVÁ, K.-HULÍNSKÝ, V., 2015: Proměny skel od 11. do 13. století v Čechách - The glass transformation in Bohemia between the eleventh century and the end of the thirteenth century, AR LXVII, 79-108.

ČERNÁ, E., ed., 1994: Středověké sklo v zemích koruny české. Katalog výstavy. Most.

DURDÍK, T., 1983: K výskytu bíle malované keramiky v Čechách (Sdělení k článku Z. Hazlbauera-J. Špačka) - Zum Vorkommen der weiss bemalten Keramik im Böhmen, AH 8, 211-213.

FLORIÁN, Č., s. d.: Topografie Chrudimi I. Rukopis, ulož. v SOkA v Chrudimi, fond Pozůstalost Vincence Floriána, kart. 1, inv. č. 16.

FROLÍK, J., 1984: Archeologické nálezy. Chrudimsko /k-t/. Chrudim.

- 1989: Archeologické památky Hlinecka a Chrastecka. Hlinsko.

- 2019: Kostel sv. Václava v Lažanech a počátky středověkého osídlení Skutečska. Díl II. Analýza - The Church of St. Wenceslas in Lažany and the Beginning of the Medieval Settlement of the Land of Skuteč. Part II. Analysis. Projekt ABG 3/2. Praha.

FROLÍK, J.-KOZÁKOVÁ, R.-MUSIL, J., 2018: Jímka 938 z Chrudimi Hradební ulice. Pokus o určení statutu jejího majitele - Abwassergrube 938 in Chrudim - Hradební Straße. Versucht einer Statusbestimmung ihres Besitzers, AH 43, 455-489. https://doi.org/10.5817/AH2018-2-9

FROLÍK, J.-KOZÁKOVÁ, R.-MUSIL, J.-VAĎUROVÁ, K., 2020: Mezi sklem a keramikou. Středověká jímka 962 z Chrudimi - Hradební ulice - Zwischen Glas und Keramik. Die mittelalterliche Abwassergrube 962 aus Chrudim - Hradební-Straße, AH 45, 445-481. https://doi.org/10.5817/AH2020-1-21

FROLÍK, J.-MÁCALOVÁ, M.-STRÁNSKÁ, P., 2016: Kostel sv. Václava v Jezbořicích (okr. Pardubice) a počátky pohřbívání u něho - St. Wenceslas Church of Jezbořice (District Pardubice) and Origin of Burials, Východočeský sborník historický 30, 5-97.

FROLÍK, J.-MUSIL, J., 2007: Záchranné archeologické výzkumy v Chrudimi v roce 2006, Zprávy České archeologické společnosti - Supplément $68,46-48$.

- 2010: Záchranný archeologický výzkum v Hradební ulici v Chrudimi v roce 2006, Chrudimský vlastivědný sborník 14, 3-28.

FROLÍK, J.-MUSIL, J.-SIGL, J., s. d.: Manuál technologických skupin středověké a novověké keramiky na Chrudimsku. Rukopis uložený na archeologickém pracovišti Regionálního muzea v Chrudimi. 
FROLÍK, J.-SIGL, J., 1990: Soubor pozdněstředověké keramiky z Chrudimi - Husovy ulice - A group of late Mediaeval pottery from the town of Chrudim (Husova Street), Studies in Post-Medieval Archaeology 1,269-284.

- 1995: Chrudimsko v raném středověku - Chrudim Region (East Bohemia) in the Early Middle Ages. Development of settlement and related structural changes - Das Chrudimer Land im Frühmittelalter. Die Entwicklung der Besiedlung und seine strukturellen Probleme. Hradec Králové.

- 1998: Chrudim v pravěku a středověku. Obrazy každodenního života - Chrudim in Prehistory and the Middle Ages. Pictures of Everyday Life - Chrudim in der Urgeschichte und im Mittelalter. Bilder aus dem Altagsleben. Chrudim.

FROLÍK, J.-STRÁNSKÁ, P.-ŠVÉDOVÁ, J., 2018: Hrochův Týnec, počátky zdejšího kostela sv. Martina a feudálního sídla - Hrochův Týnec, the beginnings of the local Church of St. Martin and of a feudal residence, ASČ 22, 971-1004.

FRÖHLICH, J., 2015: Archeologické nálezy mezzomajolik - Archeological finds of mezzomaiolica, ASČ $19,831-838$.

FRÝDA, F., 1988: Skleněné číše tzv. českého typu a jejich postavení v hmotné kultuře středověkých Čech. In: Sborník kruhu přátel Muzea hl. města Prahy 1. Společnost přátel starožitností, 175-187. Praha.

GABRIEL, F.-SMETANA, J., 1983: K vývoji výrobních okruhů červeně malované keramiky v severních Čechách - Zur Entwicklung der Produktionsbereiche rotbemalter Keramik in Nordböhmen, AH 8, 119-138.

GOŠ, V., 1983: Středověké hrnčířství v Lošticích (Pět let archeologických výzkumů města) - Mittelalterliche Töpferei in Loštice (Fünf Jahre archäologischer Untersuchungen), AH 8, 197-209.

- 2007: Loštice: město stř̌edověkých hrnčírưu. Opava.

HAZLBAUER, Z.-ŠPAČEK, J., 1987: Příspěvek k výskytu bíle malované keramiky ve středním Polabí Beitrag zum Vorkommen der weiß-bemalten Keramik im Zentral-Elbengebiet, Studie a zprávy 1985, $30-55$.

HEJNA, A., 1983: Př́spěvek ke studiu malých opevněných sídel doby přemyslovské v Čechách - Beitrag zum Studium der kleinen befestigten Herrensitze der Přemyslidenzeit in Böhmen, PA LXXIV, 366-436.

HEJNA, A.-RADOMĚRSKÝ, P., 1958: Penězokazecká dílna v jeskyni „Mincovna“ na Zlatém Koni u Koněprus - Die Münzfälscherwerkstatt in der Höhle „Mincovna“ am „Zlatý Kůn̆“ bei Koněprusy, PA XLIX, 513-558.

HETEŠ, K., 1959: A significant Contribution to the History of Bohemian Glass-Making, Czechoslovak Glass Review 14, seš. 5, 15-18.

HIMMELOVÁ, Z., 1990: Sklo ze zaniklé středověké osady Konůvky - Glasgegenstände aus der Mittelalterlichen Ortswüsung Konůvky, Acta Musei Moraviae - ČMM LXXV, 131-140.

HORÁK, J., 2007: Archeologický výzkum dvorku č. p. 40 ve Filištínské ulici v Chrudimi. Diplomová práce na FF UK, Praha.

HORSCHIK, J., 1978: Steinzeug 15. bis 19. Jahrhundert. Von Bürgel bis Muskau. Dresden.

CHVÁTAL, M.-ROUS, P.-VOKÁČ, M.-ZIMOLA, D., 2013: Střepy nádob z raně novověkých hrnčiřských dílen ledečských hrnčířu - Fragments of vessels from Early Modern-Age workshops of the potters in Ledeč, Výzkumy na Vysočině 4, 184-200.

KOZÁKOVÁ, R.-KLIKAROVÁ, L.-FROLÍK, J., 2010: Bohatý soubor skla v Chrudimi - Hradební ulice, Chrudimský vlastivědný sborník 14, 129-166.

KRAJÍC, R., 2003: Sezimovo Ústí. Archeologie středověkého města 3. Kovárna v Sezimově Ústí a analýza výrobků ze železa. Díl I. - Die Schmiede in Sezimovo Ústí und Analyse der Produkt aus Eisen. Sezimovo Ústí - Archäologie der mittelalterlichen Untertanestadt 3. Praha - Sezimovo Ústí - Tábor.

KRAJíC, R. a kol., 1998: Dům pasíře Prokopa v Táboře (Archeologický výzkum odpadní jímky v domě čp. 220) - Das Haus des Gürtlers Prokop in Tábor (Archäologische Erforschung der Abfallgrube im Haus Cnr. 220). Tábor.

KUDRNÁČ, J., 1973: Vojenský tábor z husitských válek v Klučově - Ein Militärlager aus der Zeit der Hussitenkriege in Klučov, PA LXIV, 105-142.

LACINA, M.-MUSIL, J., 2020: Aktuální stav poznání hradu Rabštejnka (okr. Chrudim) a jeho hmotné kultury - Aktueller Kentnisstand über die Burg Rabstein und über ihre materielle Kultur, CB 19, 5-56. 
LEHEČKOVÁ, E., 1975: Nové nálezy středověkého skla z Kutné Hory - Neue mittelalterliche Glasfunde aus Kutná Hora, PA LXVI, 450-485.

MAZÁČOVÁ, P., 2012: Opasek jako symbol a součást stř̌edověkého oděvu. Př́íspěvek k hmotné kultuře středověku. Praha.

MALINA, O.-MUSIL, J.-NETOLICKÝ, P., 2019: Změny sídlištních struktur v okolí Ronova nad Doubravou - Veränderungen der Siedlungsstruktur im Umland von Ronov an der Doubrava, AH 44, 855-885. https://doi.org/10.5817/AH2019-2-16

MĚříNSKÝ, Z., 1969: Přehled typů loštické keramiky, jejich vývoj a datování, VVM XXV, 89-105.

MUSIL, J., 2009: An assemblage of late Middle Age and Early Modern period ceramics from Rabštejnek Castle in the cadastral territory of Smrkový Týnec in the district of Chrudim, Studies in Post-Medieval Archaeology 3, 45-64.

- 2010: Pozdně středověký a raně novověký soubor keramiky z Chrudimi. Příspěvek k poznání nastupující novověké produkce - Late medieval and Early Modern ceramics from Chrudim, Východočeský sborník historický 17, 21-36.

- 2011: Nové středověké a raně novověké nálezy z Trhové Kamenice (okr. Chrudim, Pardubický kraj) - New Medieval and Early-Modern Discoveries in Trhová Kamenice (Chrudim District, Pardubice Region), Východočeský sborník historický 19, 59-104.

- 2011a: Příspěvek archeologie k dějinám Trhové Kamenice, okr. Chrudim - Der Beitrag von der archäologie zur Geschichte von Trhová Kamenice, Bez. Chrudim, ASČ 15, 969-988.

- 2013: Katalog archeologických nálezů z hradu Rabštejnka - Archaeological Finds from Rabštejnek Castle. Sbírky Regionálního muzea v Chrudimi 7/II. Chrudim.

- 2014: Soubor keramiky z velitelského stanoviště pod hradem Lichnicí (k. ú. Podhradí v Železných horách, okr. Chrudim) - A ceramic assemblage from the command post under Lichnice Castle (cadastral area of Podhradí v Železných horách, Chrudim District), AVČ 5, 87-111.

- 2016: Př́íspěvek k poznání hmotné kultury hradu Strádova (k. ú. Ochoz u Nasavrk, okr. Chrudim) - Ein Beitrag zur Kenntnis der matereillen Kultur der Burg Strádov, AVČ 8, 54-87.

- 2017: Počátky Lhoty u Skutče (archeologie žijící vesnice), Chrudimské vlastivědné listy 26, č. 5, $13-17$.

- 2018: Novověká jímka na hradě Košumberku, CB 18, 77-99.

- 2019: Zaniklá středověká vesnice pod Sečskou přehradou (katastrální území Seč a Hoješín, okres Chrudim) aneb Ústupky roku 1315?, Chrudimský vlastivědný sborník 23, 119-150.

- 2020: Dvakačovice čp. 86 - archeologická sonda do minulosti vesnice - House No. 86 in Dvakačovice - An archaeological survey of a village's past, Východočeský sborník historický 37, 101-148.

- 2021: Revize stavu středověkého osídlení na katastru obcí Liboměřic a Licibořic - Revision des Stands der mittelalterlichen Besiedlung auf dem Kataster der Gemeinden Liboměřice und Licibořice, AVČ 20, $236-262$.

MUSIL, J.-NETOLICKÝ, P., 2012: Zaniklá středověká a raně novověká ves Bolešov v k. ú. Spačice, okres Chrudim, Pardubický kraj - The Perished and Early-Modern-Age Village of Bolešov in the Cadastral Territory of Spačice, District of Chrudim, the Pardubice Region, Východočeský sborník historický 22, 73-114.

- 2014: Tvrziště Stoupec a jeho hospodářské zázemí. Výsledky povrchového průzkumu na k. ú. Březinka u Hoštalovic (okr. Chrudim) - Fortress Stoupec and it's economic accessories. Results of survey on the Březinka u Hoštalovic cadaster (Chrudim District), AVČ 5, 148-180.

- 2016: Nové archeologické nálezy z tzv. bojanovského újezdu (Železné hory, okres Chrudim) - New archaeological finds from so-called the Bojanov district (Železné hory, district of Chrudim, E Bohemia), Praehistorica XXXIII, č. 1-2, 275-290.

MUSIL, J.-NETOLICKÝ, P.-PREUSZ, M., 2020: Archeologie v Železných horách. Výsledky nedestruktivního archeologického výzkumu v lesním prostředí. Plzeň.

NECHVÁTAL, B., 1967: Středověká keramika z Ledče nad Sázavou - Die mittelalterliche Keramik aus Ledeč nad Sázavou, AR XIX, 542-543.

NECHVÁTAL, B.-RADOMĚŘSKÝ, P., 1963: Archeologický výzkum na tvrzi v Tleskách u Jesenice (okres Rakovník), ČNM A CXXXII, 132, 4-13. 
NEKUDA, V.-REICHERTOVÁ, K., 1968: Středověká keramika v Čechách a na Moravě - Mittelalterliche Keramik in Böhmen und Mähren. Brno.

NETOLICKÝ, P., 2009: Dřevohlinité konstrukce z vrcholně středověké Chrudimi. Diplomová práce, Fakulta filozofická, Západočeská univerzita v Plzni.

- 2010: Dřevohlinité konstrukce z vrcholně středověké Chrudimi, Chrudimský vlastivědný sborník 14 , 69-128.

NOVÁK, M., 2010: Pravěké osídlení Chrudimi - Hradební ulice, Chrudimský vlastivědný sborník 14, $29-67$.

OLCZAK, J., 2007: On glass serving as money in Medieval archaeological sources, Archaeologia Polona 45, 127-137.

PAVLŮ, I., 1982: K počátkům Čáslavě. I. Katalog - Archeologické nálezy při městských hradbách, Praehistorica X - Varia archaeologica 3, 75-160.

- 1991: K počátkům Čáslavě. II. Zhodnocení archeologických dat, Praehistorica XVIII - Varia archaeologica 5, 119-137.

PTÁK, M.-JOHN, J.-BENEŠ, J., 2018: Olověné předměty z hradiště Na Jánu v Netolicích - Bleigegenstände vom Burgwall „Na Jánu“ in Netolice, AVJČ 31, 247-252.

RADOMĚǨSKÝ, P., 1976: Příspěvek k otázce primitivních platidel 13. století. In: Sborník II. numismatického symposia, 103-119. Brno.

REICHERTOVÁ, K., 1968: Nález chlebové pece v Anežském klášteře v Praze 1, Na Františku, Na Františku, AR XVIII, 220-229, 285-286, tab. II:5.

ROZSYPALOVÁ, H., 2010: Chrudim v 9. a 10. století na základě archeologických výzkumů. Nepublikovaná bakalářská práce, Ústav historických věd, Filozofická fakulta, Univerzita Pardubice.

SEDLÁČKOVÁ, H., 2001: Gotické sklo na střední a severní Moravě v archeologických nálezech - Gotisches Glas in den archäologischen Fundun aus Mittel- und Nordmähren, AH 26, 411-428.

- 2007: From the Gothic period to the Renaissance. Glass in Moravia 1450 - circa 1560, Studies in Post-Medieval Archaeology 2, 181-226.

- 2004a: Středověké sklo z Opavy - Mittelalterliches Glas aus Opava/Troppau, PA XCV, 223-264.

- 2004b: Archeologické nálezy skla z hradu Cvilín u Krnova, okr. Bruntál - Archäologische Glasfunde auf der Burg Cvilín (Schellenburg) bei Krnov (Jägerndorf), Bezirk Bruntál (Freudental), VVM LVI, 367-379.

- 2010: Středověké sklo z Jihlavy - Medieval glass from Iglau. In: Zaměřeno na středověk. Zdeňkovi Měřínskému k 60. narozeninám (Přichystalová, R.-Ungerman, Š., edd.), 442-447. Praha.

SEDLÁČKOVÁ, H., ed., 2019: Glass in Brno and Moravia ca. 1200-1550. Assessment of finds. Vol. I. Brno.

SEDLÁČKOVÁ, L.-ZAPLETALOVÁ, D., 2012: Skleněné kroužky z Brna a problematika raně středověkého sklářství na Moravě - Glass rings from Brno and the question of early medieval glss production in Moravia, AR LXIV, 534-548.

SEHNOUTKOVÁ, P., 2011: Chrudim, Filištínská ulice čp. 39/I, odpadní jímky XIXA, XIXB a XX (příspěvek k poznání hmotné kultury). Diplomová práce na FF MU, Brno.

SCHEUFLER, V., 1972: Lidové hrnčířství v českých zemích - Volkstümliche Töpferei in den böhmischen Ländern. Praha.

STEPPUHN, P., 2002: Glasfunde des 11. bis 17. Jahrhunderts aus Schleswig. Ausgrabungen in Schleswig. Berichte und Studien 16. Neumünster.

ŠEBESTA, P., 2007: Středověké a novověké sklo z archeologických nálezů v Chebu, Sborník Západočeského muzea v Plzni, Historie XVIII, 154-160.

ŠLANCAROVÁ, V., 2018: Středověký šperk. Archeologické nálezy z jižní Moravy. Katalog nálezů. Brno. https://doi.org/10.5817/CZ.MUNI.M210-9021-2018

ŠTAJNOCHR, V.-FRÖHLICH, J.-KRAJÍC, R.-MILITKÝ, J., 1998: Katalog střepových nálezů mezzomajolik - A catalogue of mezzomajolica sherd finds, ASČ 2, 445-468.

TOMÁS̆EK, M., 1995: Archeologický výzkum hradebního pásma v Č́slavi v roce 1993 - Die archäologische Ausgrabung der Befestigungszone in Čáslav in J. 1993, AR XLVII, 444-454.

UNGER, J., 2011: Přezky s kruhovým rámečkem jako součást mužského oděvu ve středověku-Round clasps as part of men's attire in the Middle Ages, AR LXIII, 674-679. 
VAĎUROVÁ, K., 2019: Středověké skleněné kroužky z Opavy, ČSZM B LXVIII, 11-23.

VAŘEKA, P., 1998: Proměny keramické produkce vrcholného a pozdního středověku v Čechách - The erratic character of ceramic production in High and Later Middle Age in Bohemia, AR L, 123-137.

WOLF, O., 2002: K poznání hrnčířské produkce 13.-16. století v Chrudimi (archeologický výzkum ve Filištínské ulici čp. 37/I-40/I). Diplomová práce na FF MU, Brno.

ZŮBEK, A., 2002: Středověké přezky v brněnských nálezech - Medieval buckles from excavations of Brno, SPFFBU M 7, 123-153.

ŽĎÁRSKÁ, A., 2014: Středověké sklo z Prahy. Archeologické prameny k dějinám Prahy. Svazek 7. Praha.

\section{Zusammenfassung}

\section{Die Parzelle hinter Konskriptionsnr. 10/I in Chrudim. Ihre Entwicklung und Umwelt}

Die Parzelle des Hauses mit der Konskriptionsnr. 10/I in Chrudim wurde im Jahr 2006 untersucht (Abb. 1). Auf dem Hof befand sich nur eine einzige Abwassergrube (Grube 973). Die Grube war mit einem Plänermauerwerk ausgemauert (Abb. 2, 3), ihre Tiefe betrug 4,8 $\mathrm{m}$ und das Volumen $12 \mathrm{~m}^{3}$. Verfüllt war sie mit 43 Ablagerungen $(\mathrm{C} 1 / 103$ bis $\mathrm{C} 1 / 145)$. Über dem Boden befanden sich die ähnlichen Ablagerungen $\mathrm{C} 1 / 145$ bis $\mathrm{C} 1 / 139$ mit hoher Beimischung von zersetztem Holz und einer Mächtigkeit von bis zu 1,8 m. Ab dem Niveau der Ablagerungen C1/137 bis C1/131 tauchen Bruchstücke von Lehmbewurf und Mörtel auf. Eine Änderung bringen Ablagerungen $\mathrm{C} 1 / 130$ bis $\mathrm{C} 1 / 126$, bei denen es sich ihrem Charakter nach um Baueinsturz handelt. Eine weitere Ablagerung mit einem hohen Holzkohlegehalt ist eine mögliche Brandspur (C1/123), ebenso wie Ablagerung C1/121, die hauptsächlich aus Lehmbewurf besteht. Darüber befinden sich Schichten $(\mathrm{C} 1 / 116$ bis $\mathrm{C} 1 / 120)$, die den Charakter einer Isolierung haben und von Sand und einem Geröllpflaster überlagert werden (C1/113 bis C1/115 - Abb. 2B). Bestandteil des Pflasters war ein bearbeiteter Sandsteinblock (Abb. 2B, Abb. 4). Über dem Pflaster befindet sich Bauschutt $(\mathrm{C} 1 / 112-\mathrm{C} 1 / 104)$, in dem eine kleine Mauer aus Plänersteinen errichtet wurde (Abb. 2A).

Im unteren Teil besteht die Verfüllung der Grube aus Abfall vom benachbarten Haushalt mit Belegen einer gemauerten Bebauung (Mörtel mit Ziegelsteinfragmenten, Ablagerungen $\mathrm{C} 1 / 126$ bis $\mathrm{C} 1 / 130)$. Über den Brandspuren $(\mathrm{C} 1 / 121, \mathrm{C} 1 / 123)$ ändert sich die Verfüllung und es überwiegt Bauschutt. Der Verlauf der einzelnen Ablagerungen zeigt, dass sich die weichen Teile der Verfüllung nach und nach in der Grube gesetzt haben. Die entstandene Vertiefung wurde mit Aufschüttungen (C1/104 bis C1/112) aufgefüllt. Die Absenkung des Geländes betrug insgesamt $1,7 \mathrm{~m}$.

Das am häufigsten vertretene archäologische Material stellt Keramik dar (6 552 Stück; 150,4 kg). Ausgewertet wurden 446 ganze Gefäße und ihre Torsi. Die Keramik kann ihren makroskopisch erfassbaren Eigenschaften nach in 53 technologische Grundkeramikklassen mit chronologischer Bedeutung unterteilt werden (Diagramm 1). Es wurden drei Zeithorizonte untergliedert (Abb. 3). Der obere Horizont (1. Phase - Abb. 5 und 6) in der Ablagerungsspanne $\mathrm{C} 1 / 103$ bis $\mathrm{C} 1 / 114$ wird anhand der gefundenen Keramikfragmente ins 17.-18. Jahrhundert datiert. Auffällig sind blau glasierte Fragmente mit Kratzdekor (Abb. 6) aus dem Umkreis der Neuhauser (Jindřichův Hradec) Mezzo-Majolika. Importware ist durch Fragmente sächsischen und Lausitzer Steinzeugs aus dem Umfeld von Waldenburg, Bad Muskau und Triebel vertreten (Abb. 5:2-8). Es kommen auch Imitationen von Muskauer Steinzeug und zeitgenössisches rheinländisches Steinzeug vor (Abb. 5:9). Vertreten ist auch mittelböhmische weiß bemalte Keramik (Abb. 5:1) und ein Kinderspielzeug (Abb. 5:10).

Eine Änderung in der Zusammensetzung der Keramikfunde wurde auf dem Niveau der Ablagerungen $\mathrm{Cl} / 115$ und $\mathrm{Cl} / 116$ verzeichnet (2. Phase, 16.-17. Jahrhundert - Abb. 7). Dort kommt unglasierte Reduktionskeramik zur Geltung (Abb. 7:1,2, 4), nichtsdestoweniger gehörte 
die Mehrheit zur gebrannten Oxidationskeramik (Abb. 7:7). Eine Sonderstellung hat hier lokale Keramik vom Typ Husova-Straße (Abb. 7:5, 6).

Keramik aus Ablagerung $\mathrm{C} 1 / 117$ und darunter bezeichnen wir als 3./4. Horizont (Ende 14. bis Wende 15. und 16. Jahrhundert - Abb. 8-11). Ein Import aus deutscher Umgebung ist graue Keramik mit weißem Bruch (Torso eines Grapen) und metallglänzende Keramik mit „urzeitlich“ behandelter Oberfläche. Ins 14. Jahrhundert datieren wir graue Keramik mit lederartigem Überzug mit Glimmer und Sandwicheffekt und Glimmerkeramik vom Typ Zbyslavec. Eine bedeutende Stellung nimmt Protoreduktionskeramik, helle gebrannte Oxidationskeramik mit grießartiger Oberfläche und fest gebrannte Keramik mit lederartiger Oberfläche ein, die sich teilweise mit dem Umkreis von heller Oxidationskeramik mit roter Bemalung deckt. Auf dem Niveau der Ablagerungen $\mathrm{Cl} / 141$ bis $\mathrm{Cl} / 145$ ist ein Zufluss von Importkeramik zu erkennen (Loschitzer Abb. 10:9, weiß bemalte - Abb. 14:3, rot bemalte, Iglauer Becher - Abb. 10:7, glasierte - Abb. 10:2, Balsamarium - Abb. 11:4). Die Anzahl der Becher (Abb. 10) und Krüge (Abb. 9) nimmt zu.

Die Glasfragmente lassen sich in zwei Grundhorizonte unterteilen. Der an Funden reiche erste Horizont (14. bis 1. Hälfte 15. Jahrhundert) wird durch Glas mit gotischer Formgebung repräsentiert (Ablagerungen $\mathrm{C} 1 / 145$ bis $\mathrm{C} 1 / 123$ ). Am meisten davon enthielt Schicht C1/145. In ihr wurden mindestens 20 Becher böhmischen Typs mit deutlicher Variabilität in der Ausführung des Dekors gefunden (Abb. 14). Es gelang, einen 42,5 cm hohen flötenartigen Becher zu rekonstruieren (Abb. 12:6). Zwei weitere solcher Becher haben diese Höhe nicht erreicht (30 cm - Abb. 12:4, der zweite 35-40 cm). Mindestens zehn weitere Becher zählen zu den größeren flötenartigen Formen mit fast zylindrischer Mündung. Mit seiner Verzierung ragt ein mit diagonalen, mit einem Rädchen eingedrückten Fäden verzierter Becher heraus (Abb. 13:2). Die zweite Variante von Bechern böhmischen Typs sind niedrigere Becher mit deutlich keulenförmigem Korpus und abgesetzter Mündung (mindestens fünf Einzelstücke - Abb. 12:1-3; 13:6). Von ihnen oder einem anderen Bechertyp stammen die Fragmente von mehreren Gefäßmündungen (Abb. 12:8, 9) und drei Füße (Abb. 13:8, 9). Einen weiteren Typ repräsentieren Becher mit fassartigem Korpus (zwei Exemplare - Abb. 13:7, 10) und ein einfacher Becher mit fassartigem Korpus und einem Durchmesser von 6,9 cm (Abb. 13:11). Schicht C1/145 enthielt auch mehrere Fensterglasfragmente - Fensterscheiben (Abb. 13:12, 13). In den Schichten C1/145 und C1/141 wurden ziemlich korrodierte Glasfragmente vom Mittelteil eines Bechers mit einzigartigem Dekor entdeckt (Abb. 13:3). Ferner fand man Becherfragmente, die verziert waren mit einem Zickzackmuster aus glattem Faden, mit horizontalen, mit einem Rädchen eingedrückten Fäden und einem deutlich eingekerbten Band (Abb. 13:4, 5). Mit einem oder zwei Exemplaren vertreten sind flötenartige Becher mit diagonalen, mit einem Rädchen eingedrückten Fäden. Die Gesamtzahl der Gefäße betrug um die 30 Stück. Wir interpretieren diesen Fundkomplex als Ausstattung eines besser gestellten bürgerlichen Haushalts, der jedoch keine Möglichkeit hatte, Glas ausländischer Provenienz zu beziehen. $\mathrm{Zu}$ den seltenen Funden zählt ein glatter Glasring (Abb. 12:7), wie wir ähnliche bereits aus der Zeit des frühen Mittelalters kennen. Den zweiten Horizont repräsentieren Fragmente aus den Schichten C1/103-115 und C1/119) mit Glas renaissancezeitlicher Formgebung (Becherfragmente mit Fuß aus gewickeltem Glasfaden) und eine Fülle an Fensterglas - Scheiben und dreieckförmige Füllungen. Aus Schicht C1/112 stammt eine Scherbe aus hellblauem, mit dunkelblauer Bemalung verziertem Glas.

Anderes Material bildet nur einen geringen Fundanteil. Unter den Eisengegenständen identifizieren wir einen Ring (Abb. 15:10), ein Rädchenspornfragment (Abb. 15:11) und Teile eines Drehschlüssels mit runder Öse (Abb. 15:12). Der bedeutendste Bronzegegenstand ist ein Behältnis für Ampullen mit Salbölen - ein sog. Chrismatorium aus Ablagerung C1/145 (Abb. 16). Sie fand sekundär als Schatulle für Münzen Verwendung. Darauf deutet der Fund von 24 Groschen von Wenzel IV. (1378-1419) hin. Aus Blei hergestellt war ein Rädchen mit Mittelloch (Abb. 11:6), bei dem es sich um eine ältere Beimischung handelt. Gegenstände aus Bein repräsentieren ein Abfallfragment aus der Ringproduktion (Abb. 11:3) und eine Beinummantelung (Abb. 11:2). Der jüngste Horizont enthält den Abschlag eines Feuersteins (Abb. 11:5). 
Die vorliegende Arbeit wurde von der Förderagentur der Tschechischen Republik, Nr. GA 1905677S „Glas in den böhmischen Ländern von der Gotik bis zum Barock nach den in Chrudim und Brno gemachten Funden. Die Bedeutung der regionalen Produktion im europäischen Kontext“" gefördert.

PhDr. Jan Frolík, CSc., Ústav historických věd Fakulty filozofické Univerzity Pardubice, Studentská 95, 53210 Pardubice, Česká republika,frolikjano@gmail.com

Mgr. Romana Kozáková, Národní muzeum, Ústřední depozitár̆ II, Prokopa Holého 78, 41155 Terezín, Česká republika,romana_kozakova@nm.cz

PhDr. Jan Musil, Regionální muzeum v Chrudimi, Široká 86, 53701 Chrudim, Česká republika, musil@muzeumcr.cz

Mgr. Kateřina Vad'urová, Archaia Brno z. s., Bezručova 15, 60200 Brno, Česká republika, katkabreckova@seznam.cz 
